\title{
Signaling via Dopamine D1 and D3 Receptors Oppositely Regulates Cocaine-Induced Structural Remodeling of Dendrites and Spines
}

\author{
Lei Zhang ${ }^{a-c}$ Juan Li ${ }^{a, c}$ Nuyun Liu ${ }^{b}$ Bin Wang ${ }^{a, c}$ Jingjing Gu ${ }^{a, c}$ \\ Min Zhang b, c Zhitao Zhou ${ }^{\text {b, c }}$ Yong Jianga,c Lin Zhang ${ }^{\text {b, c }}$ Lu Zhanga,c

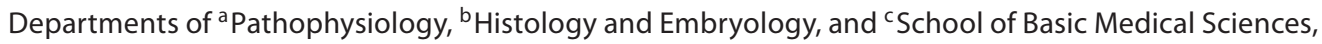 \\ Southern Medical University, Guangzhou, China
}

\section{Key Words}

Cocaine $\cdot$ Dopamine receptors $\cdot$ Signal transduction .

NMDA receptor $\cdot$ Extracellular signal-regulated kinase $\cdot$

Dendrite $\cdot$ Myocyte enhancer factor 2 activity

\begin{abstract}
Repeated exposure to cocaine can induce persistent alterations in the brain. The structural remodeling of dendrites and dendritic spines is thought to play a critical role in cocaine addiction. We previously demonstrated that signaling via dopamine D1 and D3 receptors have opposite effects on cocaine-induced gene expression. Here, we show that cocaine-induced structural remodeling in the nucleus accumbens (NAc) and caudoputamen (CPu) is mediated by D1 receptors and inhibited by D3 receptors. In addition, chronic exposure to cocaine results in an altered number of asymmetric spine synapses via the actions of both D1 and D3 receptors. The contradictory effects of D1 and D3 receptor signaling on cocaine-induced structural remodeling is associated with NMDA-receptor R1 subunit (NR1) phosphorylation, and is dependent upon the activation of extracellular signalregulated kinase (ERK). In addition, we found that D1 and D3 receptor signaling has contradictory effects upon the activation of the myocyte enhancer factor 2 (MEF2), which is involved in the dendritic remodeling after cocaine treatment. Together, these data suggest that dopamine D1 and D3 re-
\end{abstract}

\section{KARGER}

Fax +41613061234 E-Mail karger@karger.ch www.karger.com

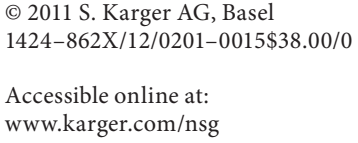

ceptors differentially regulate the cocaine-induced structural remodeling of dendrites and spines via mechanisms involving the consecutive actions of NR1 phosphorylation, ERK activation, and MEF2 activity in the NAc and CPu.

Copyright $\odot 2011$ S. Karger AG, Basel

\section{Introduction}

Drug addiction involves persistent neuroadaptations in the brain [1-5]. For example, chronic exposure to cocaine results in long-lasting increases in the number of dendrites and the density of dendritic spines in neurons located in areas of the brain involved in reward, such as the nucleus accumbens (NAc) and the caudoputamen $(\mathrm{CPu})$ [6-11]. These changes in dendritic morphology are thought to play key roles in cocaine-induced behavioral plasticity and addiction [12]. However, the intracellular signaling mechanism that controls this process is poorly understood.

Dopamine receptors, which include the D1 class (D1 and D5) and the D2 class (D2, D3, and D4), play important roles in cocaine-induced changes in the brain [13-

Lei Zhang and Juan Li contributed equally to this work.
Lu Zhang and Lin Zhang

School of Basic Medical Sciences

Southern Medical University

Tonghe, Guangzhou 510515 (China)

Tel.+86 206164 8726, E-Mail zlulu70@126.com; zlilyzh@126.com 
16]. With the use of $\mathrm{D} 1$ and $\mathrm{D} 3$ receptor mutant mice, we and others have shown that the activation of these receptors has opposite effects upon cocaine-induced locomotor activity and target gene expression [17-19]. Both acute and chronic exposure to drugs of abuse, such as cocaine and morphine, can induce phosphorylation of the NMDA-receptor R1 subunit (NR1) as well as the activation of extracellular signal-regulated kinase (ERK) in the dopaminergic system, effects that may contribute to the development of persistent changes in the brain [20-26]. In addition, the phosphorylation of NR1 and activation of ERK after acute and chronic cocaine treatment have been shown to be differentially regulated by D1 and D3 receptors [19]. Interestingly, a recent study revealed that chronic cocaine-induced dendritic spine formation is most stable in D1 receptor-expressing neurons in the NAc, indicating that D1 receptor signaling plays an important role in the long-lasting dendritic changes induced by repeated cocaine exposure [27]. A separate study found that cocaine suppresses activity of the myocyte enhancer factor 2 (MEF2) protein via the phosphorylation of MEF2 at Ser408/444 in the NAc, and this reduced activity of MEF2 contributes to the structural remodeling of dendritic spines and the sensitized responses to cocaine [28]. Importantly, this study found that D1 receptor signaling regulates MEF2 activity following cocaine exposure [28].

Although dopamine receptors have been implicated in the mechanisms underlying cocaine-induced dendritic spine formation $[27,28]$, it remains unclear whether the intracellular signaling pathways downstream of both D1 and D3 receptor activation regulate the cocaine-induced structural remodeling of dendrites and spines. In the current study, we present evidence that D1 and D3 receptor signaling have opposite effects upon the cocaine-induced structural remodeling of dendrites and spines, and that these effects are likely mediated via the consecutive events of NR1 phosphorylation, ERK activation, and MEF2 activity in the NAc and $\mathrm{CPu}$.

\section{Materials and Methods}

Mice

Kunming strain mice, $7-10$ weeks of age (mean age 8 weeks), obtained from the Southern Medical University Animals Center (Guangzhou, China) were group-housed in an animal-housing room under a 12-hour light/dark cycle with food and water available ad libitum. The Kunming mouse strain originated from Swiss mice brought to Kunming, China, from the Indian Haffkine Institute in 1944 [29]. Similar numbers of male and female mice were used in the current study. All experimental procedures were in compliance with the National Institutes of Health guidelines and were approved by the local Animal Care and Use Committee of Southern Medical University.

\section{Drugs}

Cocaine hydrochloride (Qinghai Pharmaceutical Factory, China), the D1 receptor antagonist SCH23390 (Tocris Cookson, Ballwin, Mo., USA), and the NMDA receptor antagonist MK801 (Sigma, St. Louis, Mo., USA) were dissolved in normal saline (hereinafter referred to as saline) $[19,30]$. The MEK inhibitor SL327 (Sigma) was dissolved in dimethylsulfoxide and then diluted in saline $[18,31]$. The D3 receptor antagonist NGB2904 was dissolved in PEG400 and then diluted in saline [32]. Saline was used as the vehicle ( 0 dose) control. All injections were administered intraperitoneally (i.p.) in volumes of $10 \mathrm{ml} / \mathrm{kg}$. Injections were performed during the light phase of the light/dark cycle.

\section{Drug Treatment}

For Western blotting and immunohistochemical analyses, mice $(\mathrm{n}=4-6)$ were injected with cocaine $(20 \mathrm{mg} / \mathrm{kg})$ or saline once a day for 7 days, and then analyzed $20 \mathrm{~min}, 4,12$, 24, 48, or $72 \mathrm{~h}$ following the last injection. For Golgi-Cox staining and electron microscopic analysis, mice $(n=4-8)$ were injected once daily with cocaine $(20 \mathrm{mg} / \mathrm{kg})$ or saline 5 days/week for 4 weeks, sacrificed $24 \mathrm{~h}$ following the last injection, and then analyzed for the dendritic morphology. The D1 receptor antagonist SCH23390 $(0.5 \mathrm{mg} / \mathrm{kg})$, the D3 receptor antagonist NGB2904 $(1 \mathrm{mg} / \mathrm{kg})$, and the NMDA receptor antagonist MK801 $(0.1 \mathrm{mg} / \mathrm{kg})$ were injected 30 min prior to cocaine administration, while the MEK antagonist SL327 $(30 \mathrm{mg} / \mathrm{kg})$ was injected $15 \mathrm{~min}$ prior to cocaine administration. It is important to note that saline injections, and some cocaine injections, were preceded by saline injections to control for injection stress. Comparable numbers of male and female mice were used in each group. Our drug treatment time points were based on previous findings that the gene expression pattern induced by 7 consecutive days of cocaine injections is similar to that induced by 28 days of cocaine injections, and that the time course for these changes in gene expression correlates with that for dendritic remodeling $[28,33]$.

For the pretreatment of animals with SCH23390, MK801, and SL327, doses were based on previous studies in which SCH23390 blocked cocaine target gene expression in the CPu, SL327 decreased cocaine-induced ERK activation and downstream target gene expression in the NAc and $\mathrm{CPu}$, and MK801 decreased amphetamine-induced behavioral sensitization and cocaineinduced ERK activation in the CPu $[18,19,30,31,34]$. The dose of NGB2904 pretreatment used is in accordance with previous studies in which NGB2904 enhanced cocaine-induced increases in NAc dopamine concentration and increased amphetaminestimulated locomotion $[32,35,36]$. In addition, we performed a dose-effect experiment by administering different dosages of NGB2904 (0.1, 0.5, 1, 3, and $5 \mathrm{mg} / \mathrm{kg}$ i.p.) before each cocaine treatment to confirm the selectivity of NGB2904 for D3 receptors.

\section{Dendritic Morphology and Data Analysis}

Twenty-four hours following the final injection, the brains were removed and processed for Golgi-Cox impregnation. Brains were cut into $150-\mu \mathrm{m}$ sections and medium spiny neurons and basilar dendrites of layer III somatosensory cortex pyramidal neu- 
rons were analyzed. The somatosensory cortex was used as a control brain region because it does not have a significant dopaminergic input $[37,38]$. Dendritic morphological analysis was carried out in both hemispheres of the NAc, $\mathrm{CPu}$, and somatosensory cortex using three methods [33, 39-41]. First, the dendritic complexity was calculated using a Sholl analysis of ring intersections [33, 39]. Second, the total number of dendritic branches was counted at each branch point from the cell body. Third, spine density was quantified by counting spines on the third-order (or greater) dendritic terminal tip of each medium spiny neuron and on the terminal tip of basilar dendrites from each layer III somatosensory cortex pyramidal neuron. Spines were counted from the last branch point to the terminal tip of the dendrite. Dendritic branches were counted from 8-12 neurons of each mouse in the NAc, $\mathrm{CPu}$, and somatosensory cortex. Dendritic spine density was counted at $1,000 \times$ (at least $20 \mu \mathrm{m}$ in length) from different neurons in the $\mathrm{NAc}, \mathrm{CPu}$, and somatosensory cortex of each mouse $[33,39]$. All neurons were reconstructed using Image Pro Plus version 5.1 (Media Cybernetics, Silver Spring, Md., USA), which allows three-dimensional analysis of dendritic trees. All measurements were made by a person blinded to experimental condition. Dendrites and spines were compared using one-way ANOVA followed by Bonferroni post-hoc test. Significance was set at $\mathrm{p}<0.05$.

\section{Electron Microscopy}

Twenty-four hours following the last injection, mice $(n=8)$ were briefly anesthetized with methoxyflurane and cardiac-perfused with $0.9 \%$ saline followed by freshly prepared $4 \%$ paraformaldehyde with $0.2 \%$ glutaraldehyde in $0.1 \mathrm{M}$ phosphate buffer at $\mathrm{pH} 7.4$. The brains were rapidly removed and stored in the same fixative containing $2.5 \%$ glutaraldehyde overnight at $4^{\circ} \mathrm{C}$. Coronal sections $(30 \mu \mathrm{m})$ containing NAc and $\mathrm{CPu}$ were cut using a freezing microtome. One square millimeter blocks were excised from the NAc and the $\mathrm{CPu}$ at the level of the anterior commissure. Blocks were treated with $1 \%$ osmium for $1 \mathrm{~h}$ on ice, counterstained with $2 \%$ aqueous uranyl acetate for $1 \mathrm{~h}$, dehydrated through an ascending series of ethanols, rinsed in propylene oxide, and flatembedded in Epon. The flat-embedded specimens were sectioned at $70 \mathrm{~nm}$ with an ultramicrotome and mounted on 200-mesh formvar-coated grids. Grids were stained with uranyl acetate followed by lead citrate, and examined with a transmission electron microscope (Hitachi H-7500, Japan).

Synapse counts were conducted in single ultrathin sections from the NAc and $\mathrm{CPu}$, and the number of synapses was assessed semiquantitatively. A microscopist blinded to experimental condition viewed 6 photomicrographs at $12,000 \times$ from the NAc and $\mathrm{CPu}$ of each mouse. A virtual $15 \times 11.25-\mu \mathrm{m}$ box was placed in each image. The number of asymmetric synapses located within the box was counted. Synapses were identified by the presence of pre- and postsynaptic membrane specializations, a visible synaptic cleft, and the accumulation of synaptic vesicles in the presynaptic profile $[42,43]$. Results were analyzed using one-way ANOVA followed by Bonferroni post-hoc test. Significance was set at $\mathrm{p}<0.05$.

\section{Western Blotting and Data Analysis}

The NAc and $\mathrm{CPu}$ regions were isolated by gross dissection and protein extracts were prepared as described [31]. Samples were homogenized in $300 \mu \mathrm{l}$ buffer containing 1\% NP-40, $50 \mathrm{mM}$ Tris- $\mathrm{HCl}$ (pH 7.5), 50 mM NaCl, 5 mM EDTA, 10 mM EGTA, 2 mM sodium pyrophosphate, $4 \mathrm{~mm}$ paranitrophenylphosphate, $1 \mathrm{~mm}$ sodium orthovanadate, $1 \mathrm{~mm}$ phenylmethylsulfonyl fluoride, 2 $\mu \mathrm{g} / \mathrm{ml}$ aprotinin, $2 \mu \mathrm{g} / \mathrm{ml}$ leupeptin and $2 \mu \mathrm{g} / \mathrm{ml}$ pepstatin. Homogenates were incubated on ice and centrifuged at $12,000 \mathrm{~g}$ at $4^{\circ} \mathrm{C}$. Protein concentrations were determined using the Bradford method. Twenty micrograms of total protein were separated by $10 \%$ SDS-PAGE for ERK and NR1 immunoblotting as described $[18,31]$. The resolved proteins were transferred onto PVDF membranes, and the blots were blocked in 5\% nonfat dry milk, $10 \mathrm{mM}$ Tris- $\mathrm{HCl}$ (pH 7.5), and $0.1 \%$ Tween 20 prior to incubation in primary antibodies followed by horseradish peroxidase (HRP)-conjugated secondary antibodies. Antibodies against ERK, phosphoERK, phospho-NR1 (Cell Signaling Technology, Beverly, Mass., USA) and NR1 (Upstate Inc., Lake Placid, N.Y., USA) were used at a 1:1,000 dilution, antibodies against actin (Santa Cruz) were used at a 1:3,000 dilution. The HRP-anti-rabbit conjugated secondary antibody (Santa Cruz) was used at a 1:5,000 dilution on the ERK and NR1 immunoblots. To normalize, the immunoreactive intensity of phospho-ERK and phospho-NR1 bands was divided by the intensity of total ERK and total NR1 bands, respectively. All Western blot analyses were performed at least three times, and parallel results were obtained. Statistical analysis was performed using one-way ANOVA followed by Bonferroni posthoc test. Significance was set at $\mathrm{p}<0.05$.

\section{Immunohistochemistry}

For the phospho-MEF2A (Ser408) immunostaining, 4-6 mice in each group were anesthetized and perfused with phosphatebuffered saline (PBS) followed by $4 \%$ paraformaldehyde in PBS. Brains were removed and post-fixed in $4 \%$ paraformaldehyde for $2 \mathrm{~h}$, then were cryoprotected in $20 \%$ sucrose at $4^{\circ} \mathrm{C}$ overnight. Freshly frozen coronal sections $(30 \mu \mathrm{m})$ were cut using a cryostat. Free-floating sections were blocked with $0.4 \%$ Triton- 100 and $0.1 \%$ BSA in PBS for $1 \mathrm{~h}$ and were incubated at $4{ }^{\circ} \mathrm{C}$ overnight in PBS, $0.4 \%$ Triton- 100 and $0.1 \%$ BSA containing a phosphorylation sitespecific antibody to P-Ser408 MEF2A (Cell Signaling) at 1:100 dilution. Sections were then incubated for $1 \mathrm{~h}$ at room temperature with a biotin-conjugated secondary antibody, followed a 1-hour incubation in an avidin-biotin-peroxidase complex (ABC) solution (Vector Laboratories). The sections were then developed using the diaminobenzidine (DAB) reaction. These experiments were repeated three times using multiple brain sections. Quantification of immunoreactive nuclei in DAB-stained sections from the NAc and $\mathrm{CPu}$ was performed on images captured using a light microscope with a $20 \times$ objective. Image Pro Plus software was used to count intensely labeled nuclei for each digitized image covering an area of $10 \mathrm{~mm}^{2}$ with a $5 \times$ background threshold. Data were expressed as total immunoreactive nuclei per square millimeter, or the ratio of MEF2-positive cells in cocaine- to saline-treated mice. Statistical analysis was performed using one-way ANOVA followed by Bonferroni post-hoc test. Significance was set at $\mathrm{p}<0.05$.

Immunohistochemistry for phospho-MEF2A (Ser408) and dynorphin was performed as follows. Mice $(n=4)$ were perfused $24 \mathrm{~h}$ after the last injection following 7 consecutive days of cocaine treatments. We performed two sets of controls to confirm the specificity of double immunolabeling. First, the omission of the primary antibodies resulted in no immunoreactive signal, suggesting that the secondary antibodies lack nonspecific binding to sections under the conditions used. Second, the omission of one of the two primary antibodies abolished immunoreactivity for the omitted antibody without affecting that of the other, indicating 
that the secondary antibody did not show any significant crossreactivity, and labeling sections with one antibody did not interfere with the second primary antibody. Brain sections were then incubated overnight at $4{ }^{\circ} \mathrm{C}$ in a cocktail of two primary antibodies: a phospho-specific rabbit polyclonal antibody directed against the P-Ser408 epitope of MEF2A (Cell Signaling, 1:100 dilution) and a guinea pig polyclonal antibody that recognizes prodynorphin (Abcam, 1:100 dilution) [18]. Sections were then incubated with Alexa Fluor 488-conjugated and Alexa Fluor 546-conjugated (Molecular Probes, 1:250 dilution) secondary antibodies to visualize cells immunoreactive for both phospho-MEF2A (Ser408) and dynorphin. Images of each section were captured by Image Pro Plus program. This experiment was repeated at least three times using multiple brain sections.

\section{Postnatal Prefrontal Cortex Cultures and Data Analysis}

Postnatal prefrontal cortex (PFC) neurons were isolated as described previously $[44,45]$. Briefly, postnatal day-1 Sprague-Dawley rats were decapitated and the PFC was rapidly dissected. Tissue was dissociated by incubation in $0.125 \%$ trypsin at $37^{\circ} \mathrm{C}$ for 10 $\mathrm{min}$. Cells were plated onto coverslips coated with poly-D-lysine $(100 \mu \mathrm{g} / \mathrm{ml}$, Sigma) in 24-well culture plates at a density of 20,000 cells/plate. Cells were grown in Neurobasal media (Invitrogen, Gaithersburg, Md., USA) supplemented with 2\% B27 (Invitrogen) and $0.5 \mathrm{~mm}$ glutamine with $0.5 \mu \mathrm{M}$ cytosine arabinoside (AraC) added at day in vitro (DIV) 2 .

PFC neurons were treated with PBS or the D1-receptor agonist SKF81297 (1 $\mu \mathrm{M}, 30 \mathrm{~min})$ on DIV 11, 13, and 15. Neurons were pretreated with the NMDA receptor antagonist MK801 $(20 \mu \mathrm{M})$ for $15 \mathrm{~min}$ before SKF81297 treatment. Four days following intermittent treatment, the structural remodeling of dendrites and spines on the cultured neurons was assessed. Coverslips were incubated with a mouse monoclonal antibody against MAP2 (1:1,000; Chemicon International, Temecula, Calif., USA) to visualize dendrites, or a polyclonal sheep antibody against $\gamma$-actin (1:1,000; Chemicon) to visualize dendritic spines. Primary antibodies were detected using anti-mouse Alexa Fluor 546- or antisheep Alexa Fluor 488-conjugated secondary antibodies (1:600; Molecular Probes Invitrogen, Carlsbad, Calif., USA). In the current study, we defined dendritic spines to be round or mushroomshaped, and $<3 \mu \mathrm{m}$ long [46]. For each experimental group, cells from at least 3 different coverslips were used and approximately 8 cells from each coverslip were analyzed. All images were acquired using Image Pro Plus version 5.1 (Media Cybernetics, Silver Spring, Md., USA). Data from the different groups were compared using one-way ANOVA followed by Bonferroni post-hoc test. Significance was $\mathrm{p}<0.05$.

\section{Results}

Cocaine-Induced Structural Remodeling of Dendrites and Spines Is Promoted by D1 Receptor and Inhibited by D3 Receptor Activation

We and others have previously found that the dopamine D1 and D3 receptors make opposing contributions to cocaine-induced locomotor activity and cocaine-induced gene expression [17-19, 31, 47]. To determine the role of dopamine receptors in the cocaine-induced structural remodeling of dendrites and dendritic spines in the $\mathrm{NAc}$ and $\mathrm{CPu}$, we used a well-established cocaine treatment protocol to induce dendritic spines in the NAc [41]. Mice were treated with cocaine or saline 5 days/week for 4 weeks, and dendritic morphological analyses were conducted. The D1 receptor inhibitor SCH23390 and the D3 receptor antagonist NGB2904 were administered 30 min prior to cocaine or saline injections, respectively. The treatment paradigm is indicated below the images (fig. 1F). Measurements were made by 2 investigators blind to experimental conditions. As shown in figure 1A$\mathrm{D}$, repeated cocaine injections led to an increase in dendritic branching $(22.2 \%$ more in NAc: $23.44 \pm 0.643$ vs. $19.17 \pm 0.624, \mathrm{p}<0.001, \mathrm{n}=48$ neurons; $23.3 \%$ more in CPu: $30.88 \pm 0.908$ vs. $25.04 \pm 1.036, \mathrm{p}<0.001, \mathrm{n}=48$ neurons) and spine density (28.1\% more in NAc: $12.3 \pm$ 0.38 vs. $9.6 \pm 0.27, \mathrm{p}<0.001, \mathrm{n}=45$ dendrites; $29.4 \%$ more in $\mathrm{CPu}: 12.4 \pm 0.42$ vs. $9.58 \pm 0.31, \mathrm{p}<0.001, \mathrm{n}=$ 45 dendrites) of the medial spiny neurons.

Interestingly, pretreatment of mice with NGB2904 increased the number of dendrites by $11.1 \%$ in the NAc $(26.04 \pm 0.756$ vs. $23.44 \pm 0.643, \mathrm{p}=0.034, \mathrm{n}=48$ neurons) and by $11.8 \%$ in the $\mathrm{CPu}(34.52 \pm 0.992$ vs. 30.88 $\pm 0.908, \mathrm{p}=0.021, \mathrm{n}=48$ neurons). NGB2904 pretreatment also increased spine density by $13.8 \%$ in the NAc ( 14 \pm 0.43 vs. $12.3 \pm 0.38, \mathrm{p}=0.002, \mathrm{n}=45$ dendrites) and by $12.1 \%$ in the $\mathrm{CPu}(13.87 \pm 0.43$ vs. $12.4 \pm 0.42, \mathrm{p}=$

Fig. 1. Opposite regulation of dendritic branching and dendritic spine density of MSNs in the NAc and CPu by D1 and D3 receptors after repeated cocaine treatment. Mice were treated with cocaine $(20 \mathrm{mg} / \mathrm{kg})$ or saline once a day for 4 weeks and then the dendritic morphological analyses were performed. The D1 receptor inhibitor SCH23390 (0.5 mg/kg), the D3 receptor antagonist NGB2904 $(1 \mathrm{mg} / \mathrm{kg})$ and saline were administered $30 \mathrm{~min}$ before cocaine or saline administration. A Representative dendritic branching images of MSNs for the NAc and CPu. Scale bar $10 \mu \mathrm{m}$. B Representative dendritic spine images of MSNs for the NAc and $\mathrm{CPu}$. Scale bar $10 \mu \mathrm{m}$. C, D Quantification of dendritic branching (C) and dendritic spine density (D). Data represent mean \pm SEM; $\mathrm{n}=4-6$ mice. ${ }^{*} \mathrm{p}<0.05$ compared with saline-treated mice; ** $\mathrm{p}<0.05$ compared with cocaine-treated mice (for dendritic branching, $\mathrm{F}_{(3,188)}=12.929$ for $\mathrm{NAc}$ and $\mathrm{F}_{(3,188)}=33.047$ for $\mathrm{CPu}$; for spine density, $F_{(3,176)}=38.609$ for $\mathrm{NAc}$ and $\mathrm{F}_{(3,176)}=30.176$ for $\mathrm{CPu})$. $\mathbf{E}$ The changes in dendrite complexity in the NAc and $\mathrm{CPu}$ revealed by Sholl analysis of the intersection number per $20 \mu \mathrm{m}$ radial unit distance from soma of MSNs. $n=4-6$ mice. ${ }^{*} \mathrm{p}<0.05$ compared with saline-treated mice; ${ }^{*} \mathrm{p}<0.05$ compared with cocaine-treated mice. $\mathbf{F}$ Cocaine treatment regimens: Sal $/ \mathrm{Sal}=$ Saline/saline; Sal/Coc = saline/cocaine; SCH/Coc $=$ SCH23390/ cocaine; NGB/Coc = NGB2904/cocaine. 


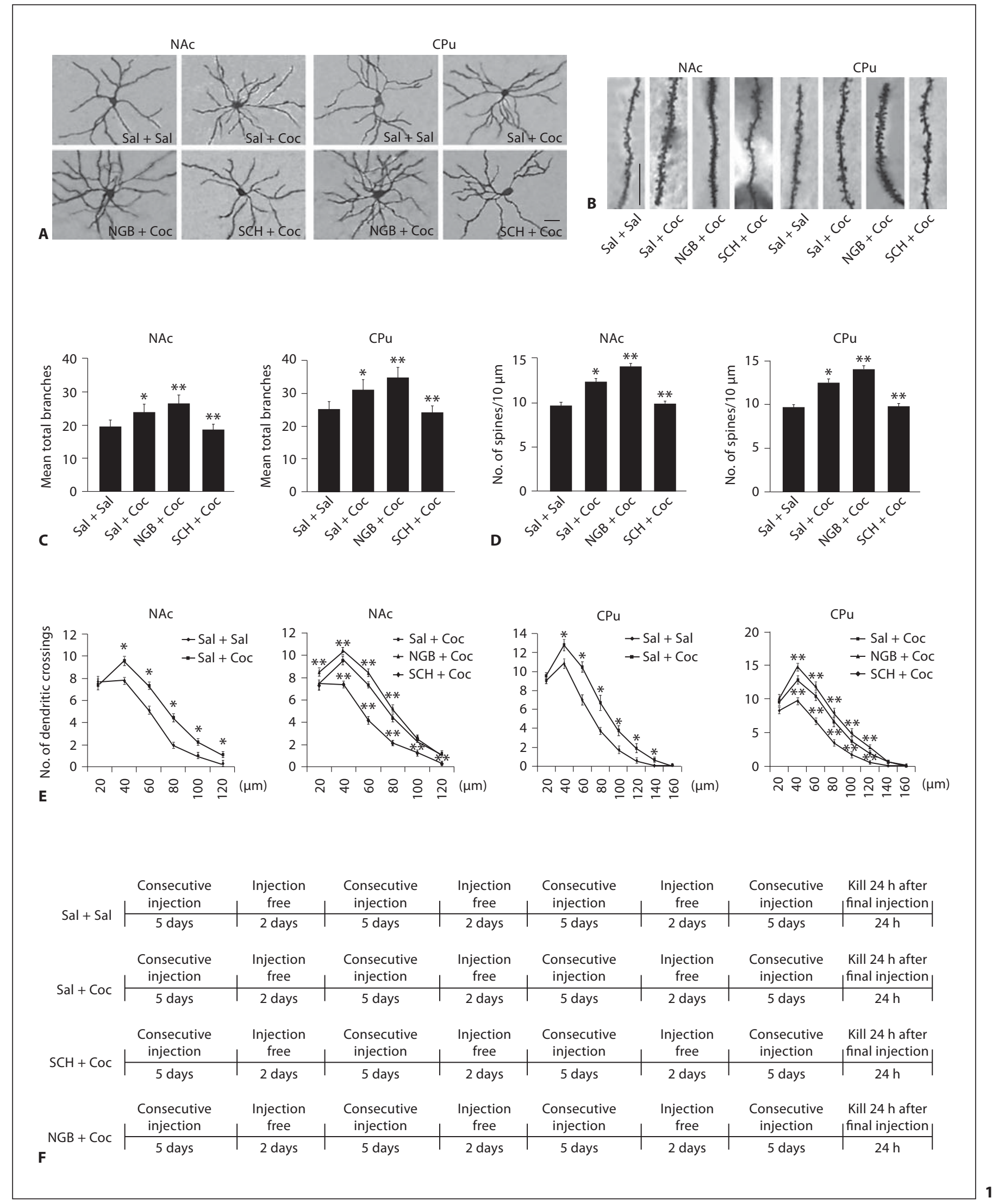


$0.04, \mathrm{n}=45$ dendrites) of MSNs. In contrast, pretreatment of mice with SCH23390 inhibited the cocaine-induced increase in the number of dendrites $(22.6 \%$ fewer in the NAc, $18.13 \pm 0.601$ vs. $23.44 \pm 0.643, \mathrm{p}<0.001, \mathrm{n}=48$ neurons; $22.7 \%$ fewer in the $\mathrm{CPu}, 23.88 \pm 0.39$ vs. 30.88 $\pm 0.908, \mathrm{p}<0.001, \mathrm{n}=48$ neurons) and spine density (20.3\% fewer in NAc, $9.8 \pm 0.26$ vs. $12.3 \pm 0.38$, p < $0.001, \mathrm{n}=45$ dendrites; $22.0 \%$ fewer in $\mathrm{CPu}, 9.67 \pm 0.37$ vs. $12.4 \pm 0.42, \mathrm{p}<0.001, \mathrm{n}=45$ dendrites) of MSNs.

As a complementary measurement of dendritic complexity, we performed a standard Sholl analysis, which counts the number of dendritic intersections with concentric circles centering on the cell soma and spaced 20 $\mu \mathrm{m}$ apart. As shown in figure $1 \mathrm{E}$, we observed an increased dendritic complexity following repeated cocaine treatment compared to saline-treated mice, represented by an increased number of dendritic intersections in the $\mathrm{NAc}$ and $\mathrm{CPu}$ from cocaine-treated mice. Pretreatment of mice with SCH23390 reduced the number of dendritic intersections in the NAc and $\mathrm{CPu}$ (fig. 1E). In contrast, pretreatment of mice with NGB2904 increased the number of dendritic intersections in the NAc and $\mathrm{CPu}$. Numerical data from the Sholl analyses are presented in online supplementary table S1-1 (for all online suppl. material, see www.karger.com/doi/10.1159/000330743). The number of dendrites and the spine densities on medium spiny neurons in the NAc and $\mathrm{CPu}$ were similar between the mice treated with SCH23390 or NGB2904 alone compared with saline-treated mice (online suppl. fig. S1). In addition, the observed alterations in the $\mathrm{NAc}$ and $\mathrm{CPu}$ following repeated cocaine treatment appear to be specific, as no obvious effects of cocaine were observed on the dendritic branching and spine density in the basilar dendrites of layer III somatosensory cortex pyramidal neurons (online suppl. fig. S2).

NGB2904 has been reported to have a greater than 150 -fold selectivity for primate $\mathrm{D} 3$ over $\mathrm{D} 2$ receptors, and an 800 -fold selectivity for rat D3 versus D2 receptors [48, 49]. A number of in vivo studies further support the selectivity of NGB2904 for D3 receptors [32, 35, 36]. To confirm the selectivity of NGB2904 in our experiments, we conducted a dose-response experiment by treating mice with different dosages of NGB2904 (0.1, 0.5, 1, 3, and $5 \mathrm{mg} / \mathrm{kg}$, i.p.) prior to each cocaine treatment. We found that there was a significant difference between the different NGB2904 treatment groups on measures of dendritic branching $\left(\mathrm{CPu}, \mathrm{F}_{(5,282)}=12.779, \mathrm{p}<0.001\right.$; NAc, $\left.\mathrm{F}_{(5,282)}=13.806, \mathrm{p}<0.001\right)$ and spine density $(\mathrm{CPu}$, $\mathrm{F}_{(5,264)}=11.911, \mathrm{p}<0.001 ; \mathrm{NAc}, \mathrm{F}_{(5,264)}=13.107, \mathrm{p}<0.001$; online suppl. table S2). Although we observed a trend to- wards an increased effect on dendritic remodeling with escalating NGB2904 doses, only dosages in the range of $1-5 \mathrm{mg} / \mathrm{kg}$ (i.p.) significantly increased cocaine-induced dendritic branching and spine density (online suppl. fig. S3). Individual group comparisons using Bonferroni post-hoc tests revealed statistically significant differences between the 0.1 - and 1-mg/kg NGB2904 groups (dendritic branching in $\mathrm{CPu}, 30.71 \pm 0.735$ vs. $34.1 \pm 0.823, \mathrm{p}=$ 0.041; dendritic branching in NAc, $23.52 \pm 0.619$ vs. $26.19 \pm 0.576, \mathrm{p}=0.024$; spine density in $\mathrm{CPu}, 12.78 \pm$ 0.19 vs. $13.93 \pm 0.325, \mathrm{p}=0.043$; spine density in NAc, $12.51 \pm 0.359$ vs. $13.96 \pm 0.313, \mathrm{p}=0.029)$ and between the $1-$ and $5-\mathrm{mg} / \mathrm{kg}$ groups (dendritic branching in $\mathrm{CPu}$, $34.1 \pm 0.823$ vs. $37.6 \pm 0.674, p=0.03$; dendritic branching in NAc, $26.19 \pm 0.576$ vs. $28.9 \pm 0.607, \mathrm{p}=0.025$; spine density in $\mathrm{CPu}, 13.93 \pm 0.325$ vs. $15.09 \pm 0.318$, $\mathrm{p}=0.044$; spine density in NAc, $13.96 \pm 0.313$ vs. $15.33 \pm$ $0.242, p=0.045$; online suppl. table S2). Together, these results indicate that the $\mathrm{D} 1$ receptor activity positively regulates cocaine-induced structural remodeling of dendrites and dendritic spines in the $\mathrm{NAc}$ and $\mathrm{CPu}$, while D3 receptors negatively regulate cocaine-induced remodeling.

\section{Chronic Exposure to Cocaine Results in Altered \\ Numbers of Asymmetric Spine Synapses Mediated via the Dopamine D1 and D3 Receptors \\ A recent report demonstrated that prenatal exposure} to cocaine is associated with an increased number of asymmetric spine synapses [50]. To determine cocaineinduced changes in striatal dendrites in more detail, we evaluated the number of asymmetric spine synapses in the NAc and $\mathrm{CPu}$ following repeated cocaine treatment using transmission electron microscopy (EM). As shown in figure 2, the estimated number of excitatory asymmetric synapses was significantly increased in both the NAc and $\mathrm{CPu}$ following repeated exposure to cocaine $(28.8 \%$ more in NAc: $20.1 \pm 0.308$ vs. $15.6 \pm 0.25, \mathrm{p}<0.001$, $\mathrm{n}=48$ images; $25.2 \%$ more in $\mathrm{CPu}: 20.38 \pm 0.296$ vs. $16.27 \pm 0.243, \mathrm{p}<0.001, \mathrm{n}=48$ images).

To further determine whether the observed increases in asymmetric spine synapse number depends upon dopamine receptor signaling, we treated mice with either SCH23390 or NGB2904 prior to cocaine treatment. We found that the number of asymmetric spine synapses was enhanced in the NAc and CPu of NGB2904-pretreated mice $(12.9 \%$ more in NAc: $22.69 \pm 0.418$ vs. $20.1 \pm 0.308$, $\mathrm{p}=0.002, \mathrm{n}=48$ images; $11.1 \%$ more in $\mathrm{CPu}: 22.65 \pm$ 0.324 vs. $20.38 \pm 0.296, \mathrm{p}=0.008, \mathrm{n}=48$ images) and reduced in the SCH23390-pretreated mice (23.2\% fewer 
A
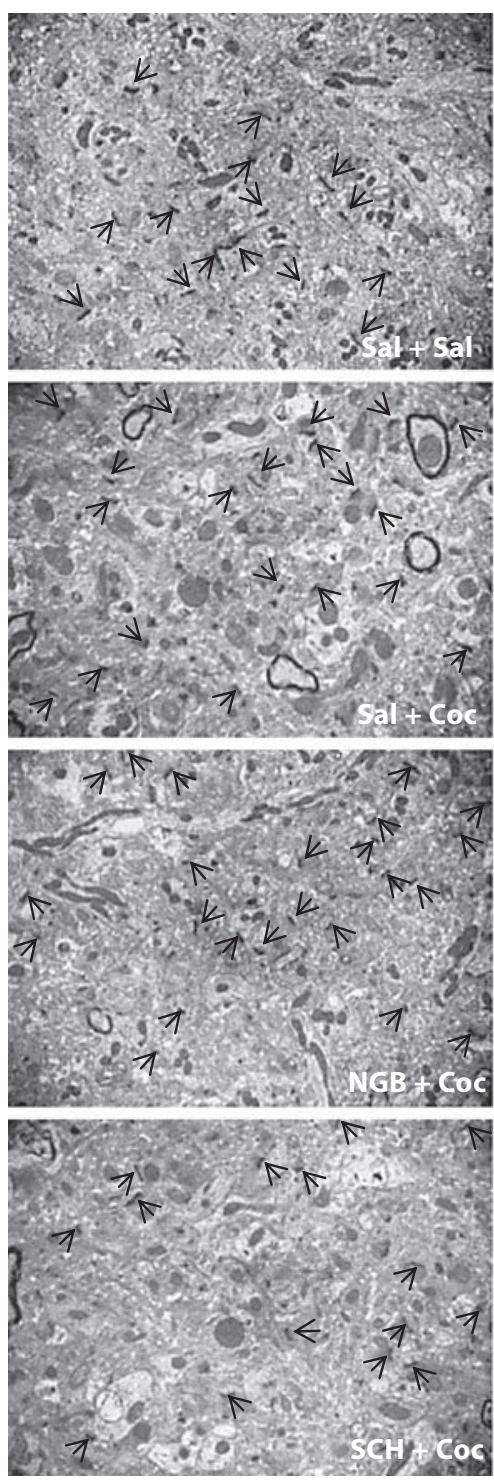

B
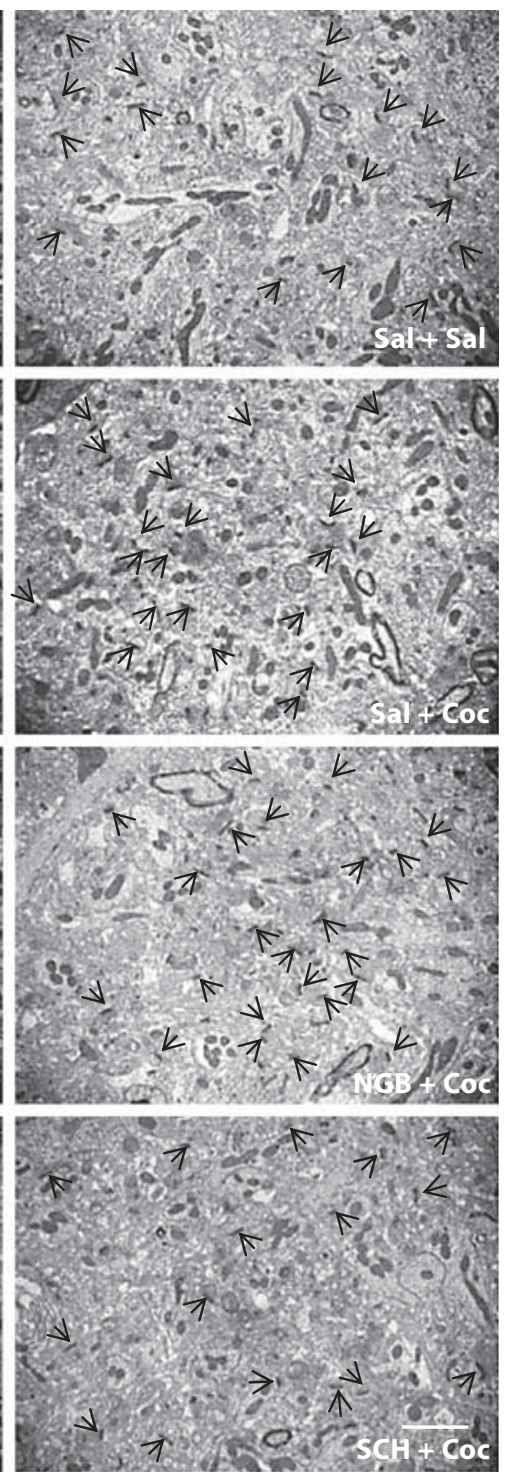

C
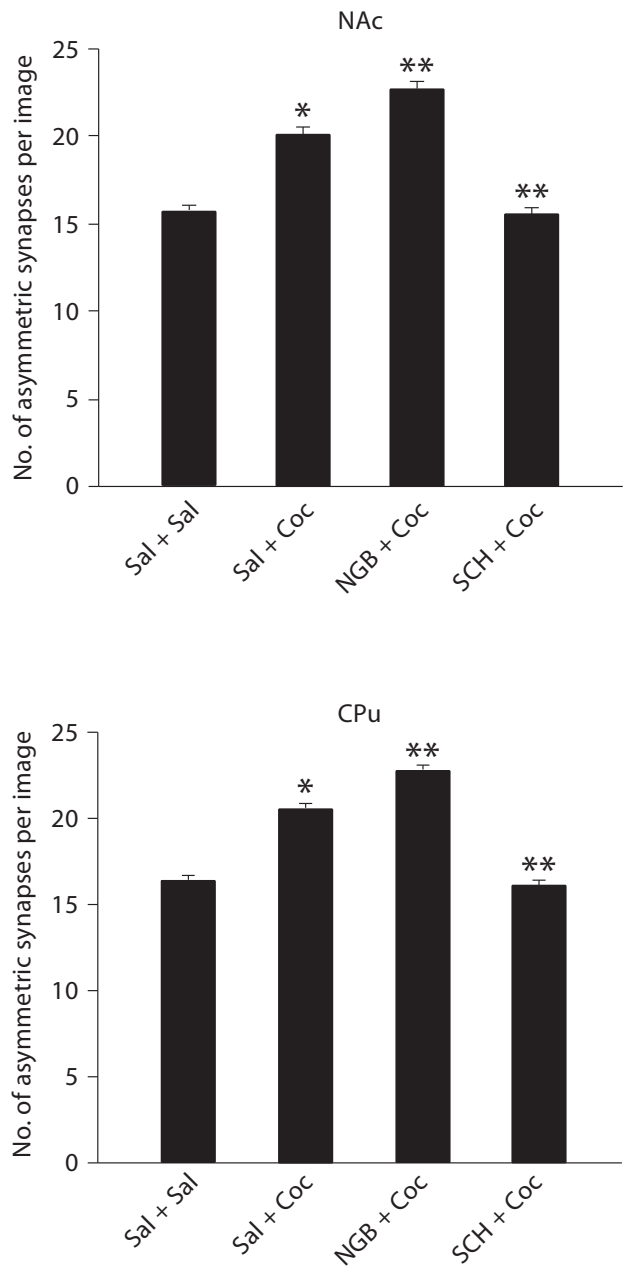

Fig. 2. Chronic exposure to cocaine results in altered numbers of asymmetric spine synapses in the NAc and CPu through the dopamine D1 and D3 receptors. A, B Representative photomicrographs of electron microscopic images of the sampled regions within the NAc (A) and $\mathrm{CPu}(\mathbf{B})$ in the indicated groups of mice. Arrows indicate asymmetric spine synapses. Scale bar $2 \mu \mathrm{m}$.
C The estimated number of asymmetric spine synapses in the NAc and $\mathrm{CPu}$ in the indicated groups of mice. Data represent the number of asymmetric synapses (mean \pm SEM) that fell into a box $(15 \times 11.25 \mu \mathrm{m}) .{ }^{*} \mathrm{p}<0.05$ compared with saline-treated mice; ** $\mathrm{p}<0.05$ compared with cocaine-treated mice $\left(\mathrm{F}_{(3,188)}=\right.$ 127.55 for $\mathrm{NAc}$ and $\mathrm{F}_{(3,188)}=137.71$ for $\left.\mathrm{CPu}\right)$. in NAc: $15.43 \pm 0.208$ vs. $20.1 \pm 0.308, \mathrm{p}<0.001, \mathrm{n}=48$ images; $21.2 \%$ fewer in $\mathrm{CPu}$ : $16.06 \pm 0.224$ vs. $20.38 \pm$ $0.296, \mathrm{p}<0.001, \mathrm{n}=48$ images). These findings indicate that chronic cocaine exposure induces alterations in the number of asymmetric spine synapses in the NAc and $\mathrm{CPu}$ that are positively and negatively regulated by dopamine D1 and D3 receptors, respectively.

D1 and D3 Receptor Signaling Mediates Cocaine-Induced Dendritic Changes
The Differential Effects of D1 and D3 Receptor Activity upon Cocaine-Induced Structural Remodeling Are Associated with the Phosphorylation of NR1

NMDA receptors play key roles in the activity-dependent structural remodeling of dendritic arbors and spines [51-54]. Importantly, NMDA receptors have been implicated in cocaine-induced neuroadaptation [55-57]. Our 


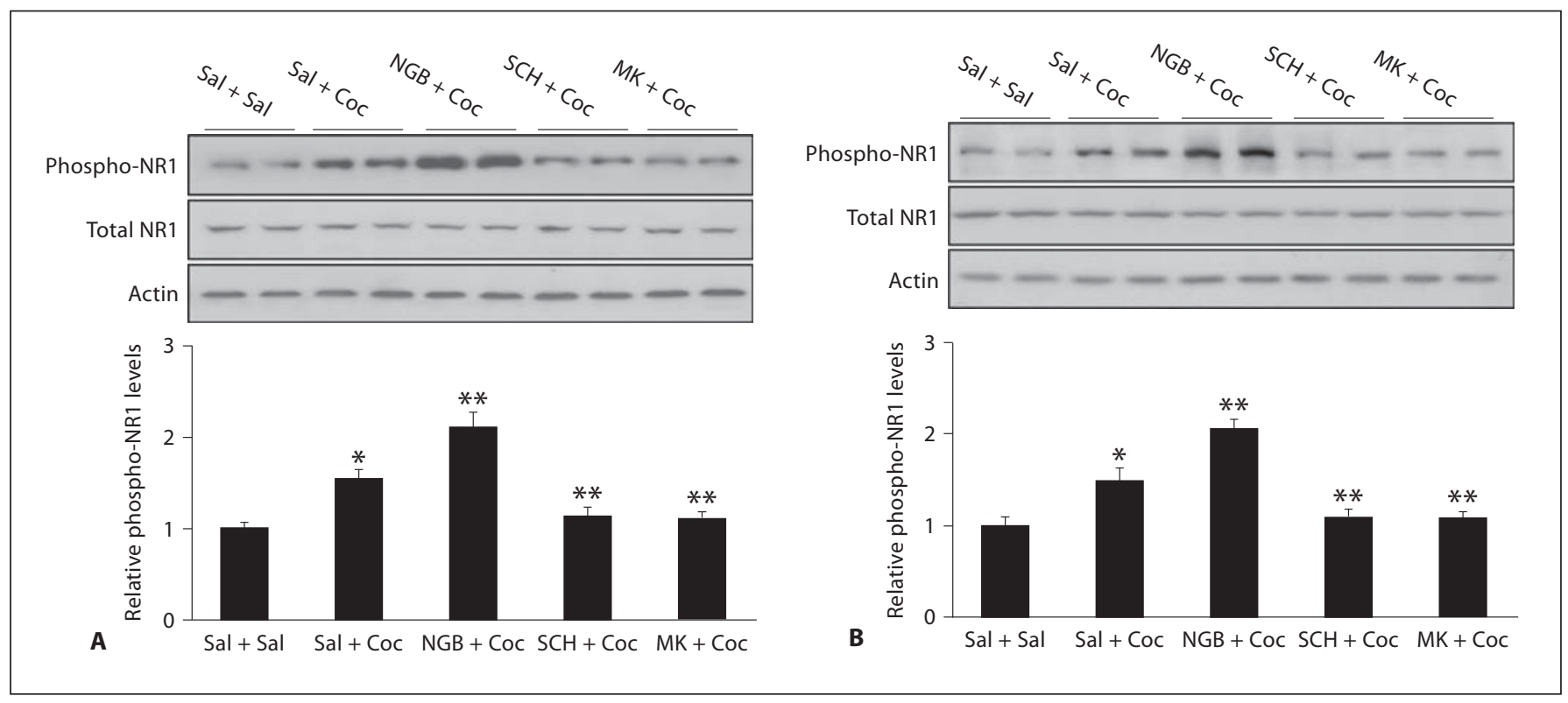

Fig. 3. Opposite regulation of NR1 phosphorylation in the NAc and $\mathrm{CPu}$ by $\mathrm{D} 1$ and $\mathrm{D} 3$ receptors after repeated cocaine treatment. Mice $(\mathrm{n}=4-6)$ were treated with cocaine $(20 \mathrm{mg} / \mathrm{kg})$ or saline once a day for 7 days. The D1 receptor inhibitor SCH23390 (0.5 $\mathrm{mg} / \mathrm{kg}$ ), the D3 receptor antagonist NGB2904 (1 mg/kg), the NMDA receptor inhibitor MK801 $(0.1 \mathrm{mg} / \mathrm{kg})$ and saline were administered 30 min before cocaine or saline injections. The NAc
(A) and $\mathrm{CPu}(\mathbf{B})$ protein extracts were prepared 20 min after the last injection. Western blot analyses were performed using antibody against phosphorylated (Ser897) NR1, total NR1 and actin. Data represent the mean \pm SEM. Saline-treated levels were set at 1 for quantifications. ${ }^{*} \mathrm{p}<0.05$ compared with saline-treated levels; ${ }^{* *} \mathrm{p}<0.05$ compared with cocaine-treated levels (for NAc, $\mathrm{F}_{(4,21)}=122.569$, for $\left.\mathrm{CPu}, \mathrm{F}_{(4,21)}=199.10\right)$. previous work suggests that D1 and D3 receptors differentially modulate the NMDA-induced phosphorylation of NR1, specifically at Ser897 [19]. In addition, Ser897 phosphorylation is necessary for D1 receptor-mediated gene expression [24]. Therefore, we speculated that D1 and $\mathrm{D} 3$ receptor activity might mediate cocaine-induced structural remodeling of dendrites and spines by influencing NR1 activity at Ser897. To test this possibility, we first determined the effects of D1 and D3 receptor activity upon cocaine-induced phosphorylation of NR1 in the striatum. We treated mice with SCH23390, NGB2904, or MK801 30 min prior to each cocaine injection. We then prepared protein extracts from the $\mathrm{CPu}$ and NAc $20 \mathrm{~min}$ following the final injection and performed Western blot analyses for NR1 activation using an anti-phospho-NR1 (Ser897) antibody. As shown in figure 3, chronic cocaine treatment induced significant Ser897 phosphorylation 20 min following the final cocaine injection in the NAc (fig. 3A) and $\mathrm{CPu}$ (fig. 3B). Ser897 phosphorylation was enhanced in the NAc and CPu in NGB2904-pretreated mice, and inhibited in SCH23390-pretreated mice. Similarly, cocaine-induced Ser897 phosphorylation was inhibited in MK801-pretreated mice. These results suggest that the chronic cocaine-induced phosphorylation of NR1 at Ser897 in the NAc and CPu is differentially regulated by $\mathrm{D} 1$ and $\mathrm{D} 3$ receptor activity.

We then sought to determine whether NMDA receptors contribute to the increased number of dendrites and dendritic spines observed following chronic cocaine treatment. We treated mice with MK801, 5 days/week for 4 weeks, prior to cocaine or saline injection, and then performed morphological analyses. We found that pretreatment of mice with MK801 prevented cocaine-induced increases in the number of dendrites $(22.0 \%$ fewer in NAc: $18.29 \pm 0.648$ vs. $23.44 \pm 0.643, \mathrm{p}<0.001, \mathrm{n}=$ 48 neurons; $25.9 \%$ fewer in $\mathrm{CPu}: 25.88 \pm 0.641$ vs. 30.88 $\pm 0.908, \mathrm{p}<0.001, \mathrm{n}=48$ neurons; fig. $4 \mathrm{~A}, \mathrm{C})$ and spine density (18.3\% fewer in NAc: $10.07 \pm 0.3$ vs. $12.3 \pm 0.38$, $\mathrm{p}<0.001, \mathrm{n}=45$ dendrites; $17.7 \%$ fewer in CPu: $10.22 \pm$ 0.345 vs. $12.4 \pm 0.42, \mathrm{p}<0.001, \mathrm{n}=45$ dendrites; fig. $4 \mathrm{~B}$, D). Sholl analysis indicated that the dendrite branching pattern was reduced in MK801 pretreated, compared to not pretreated, cocaine-treated mice in the $\mathrm{NAc}$ and $\mathrm{CPu}$ (fig. 4E; online suppl. table S1-2). The number of dendrites and spine density of MSNs in the NAc and $\mathrm{CPu}$ were similar in mice treated with MK801 alone compared 


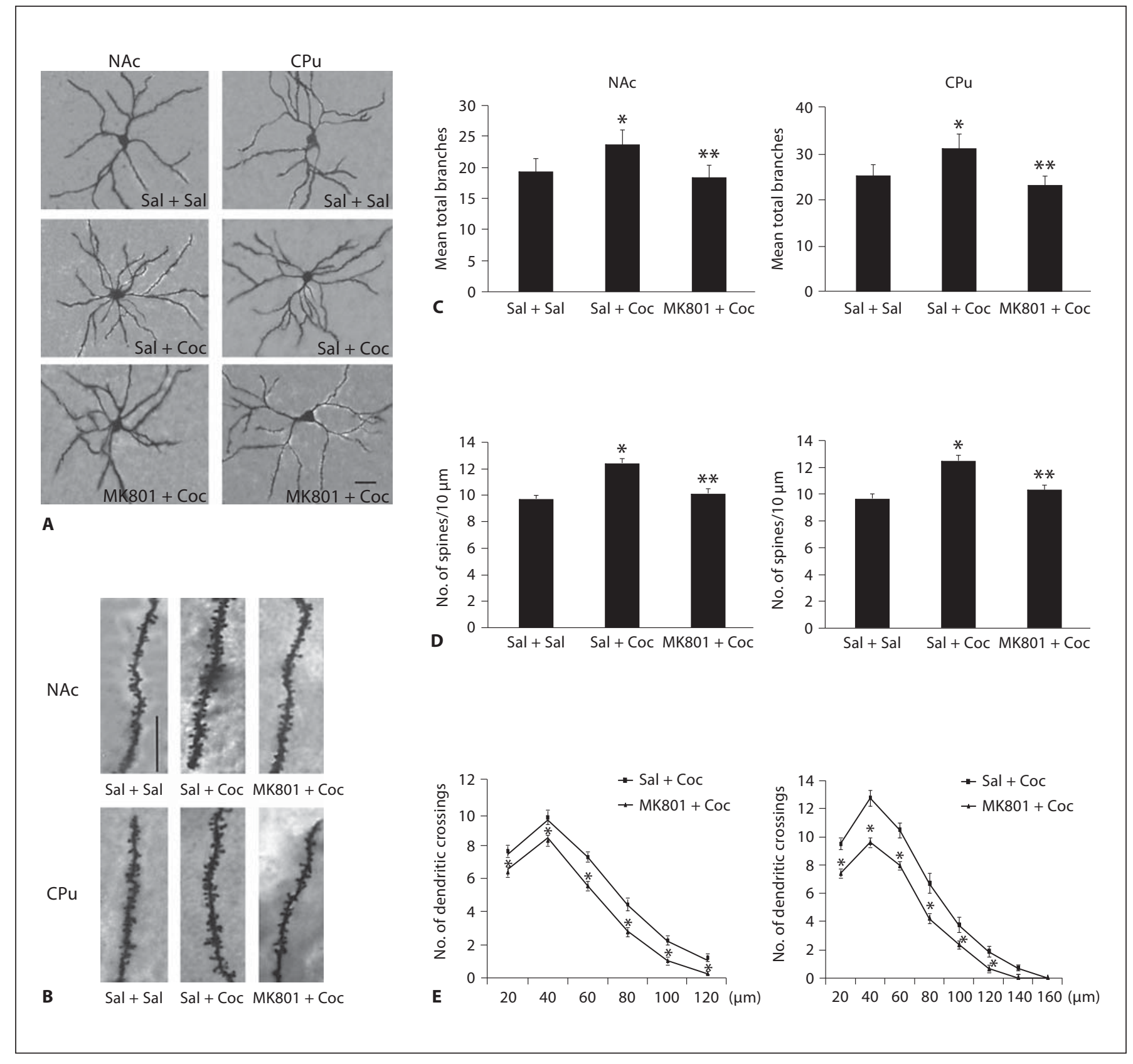

Fig. 4. Inhibition of NMDA receptors inhibits the structural remodeling of dendrites and spines of MSNs in the NAc and CPu after repeated cocaine treatment. Mice were treated with cocaine (20 mg/kg dose) or saline once daily for 4 weeks and then the dendritic morphological analyses were performed. The NMDA receptor inhibitor MK801 $(0.1 \mathrm{mg} / \mathrm{kg})$ and saline were administered 30 min before cocaine or saline injections. A Representative dendritic branching images of MSNs for the NAc and CPu. Scale bar $10 \mu \mathrm{m}$. B Representative dendritic spine images of MSNs for the NAc and CPu. Scale bar $10 \mu \mathrm{m}$. C, D Quantification of dendritic branching $(\mathbf{C})$ and dendritic spine density (D) in the indicated groups of mice. Data represent mean \pm SEM. ${ }^{*} \mathrm{p}<0.05$ compared with saline-treated mice; ${ }^{* *} \mathrm{p}<0.05$ compared with cocainetreated mice (for dendritic branching, $\mathrm{F}_{(2,141)}=18.60$ for NAc and $\mathrm{F}_{(2,141)}=12.929$ for $\mathrm{CPu}$; for spine density, $\mathrm{F}_{(2,132)}=20.113$ for $\mathrm{NAc}$ and $\mathrm{F}_{(2,132)}=16.795$ for $\left.\mathrm{CPu}\right)$. $\mathbf{E}$ The changes in dendrite complexity in the NAc and CPu revealed by Sholl analysis of the intersection number per $20 \mu \mathrm{m}$ radial unit distance from soma of MSNs. Statistical analysis was performed using one-way ANOVA followed by Bonferroni post-hoc test. Data represent mean \pm SEM. ${ }^{*} \mathrm{p}<0.05$ compared with cocaine-treated mice. 


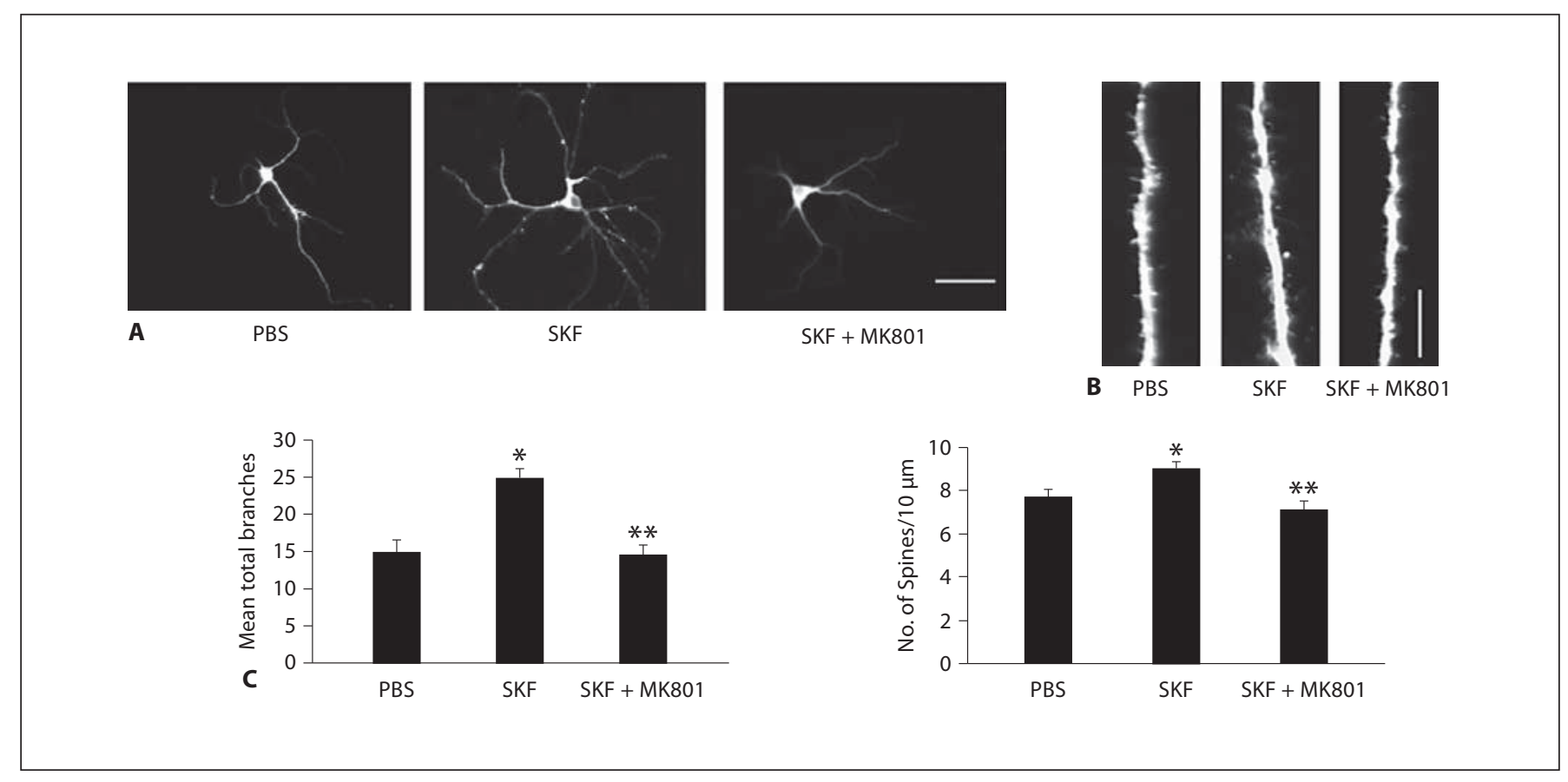

Fig. 5. Inhibition of NMDA receptors suppresses the structural remodeling of dendrites and spines of PFC neurons induced by D1 receptor agonist treatment. PFC neurons were treated with either PBS or the D1-like agonist SKF81297 (1 $\mu \mathrm{m}, 30 \mathrm{~min})$ on days 11,13 and 15 in culture. The NMDA receptor antagonist MK801 $(20 \mu \mathrm{m})$ were pre-incubated 15 min before SKF81297 treatment. Four days after intermittent treatment, cells were analyzed for the structural remodeling of dendrites and spines.
A Representative dendritic branching images of PFC neurons. B Representative dendritic spine images of PFC neurons. C, D Quantification of dendritic branching (C) and spine density (D) in the indicated groups of neurons. Data represent mean \pm SEM. ${ }^{*} \mathrm{p}<0.05$ compared with PBS-treated neurons; ${ }^{*} \mathrm{p}<$ 0.05 compared with neurons treated only with $\operatorname{SKF}\left(\mathrm{F}_{(2,69)}=\right.$ 167.62 for dendritic branching and $\mathrm{F}_{(2,69)}=74.39$ for spine density). with that in saline-treated mice (online suppl. fig. S1). Thus, NMDA receptor activity is required for the cocaine-induced structural remodeling of dendrites and dendritic spines in the NAc and $\mathrm{CPu}$.

To determine whether D1 receptors act via NMDA receptors to mediate cocaine-induced remodeling, we tested whether MK801 would block the dendritic changes induced by a D1 receptor agonist in cultured PFC neurons. PFC neurons were treated with PBS or the D1-like agonist SKF81297 on DIV 11, 13, and 15. Four days after treatment, dendrites and dendritic spines were analyzed. As shown in figure 5, SKF81297 treatment led to an increase in dendritic branching $(14.83 \pm 0.51$ vs. $24.75 \pm$ $0.41, \mathrm{p}<0.001, \mathrm{n}=24$ neurons) and spine density (7.68 \pm 0.36 vs. $9.043 \pm 0.27, \mathrm{p}<0.001, \mathrm{n}=24$ dendrites) in cultured PFC neurons compared to the PBS-treated group. Importantly, MK801 pretreatment inhibited the SKF81297-induced increase in dendritic branching (14.41 \pm 0.43 vs. $24.75 \pm 0.41, \mathrm{p}<0.001, \mathrm{n}=24$ neurons) and spine density $(7.07 \pm 0.48$ vs. $9.043 \pm 0.27, \mathrm{p}<0.001$, $\mathrm{n}=24$ dendrites), suggesting that the effects of D1 receptor activation on dendritic remodeling may be mediated via NMDA receptor signaling. These results indicate that the opposing effects of D1 and D3 receptor signaling upon cocaine-induced structural remodeling may require the activity of NMDA receptors.

\section{D1 and D3 Receptor Signaling-Mediated ERK Activation Contributes to the Cocaine-Induced Structural Remodeling of Dendrites and Dendritic Spines}

As cocaine exposure induces ERK activation in the striatum [21], and the regulation of cocaine-induced gene expression by both dopamine receptors and NMDA receptors depends upon ERK activation [18, 19, 25], we hypothesized that ERK activation may be required for the differential effects of D1 and D3 receptor signaling upon cocaine-induced structural remodeling in the striatum. To test this hypothesis, we treated mice once daily for 7 days with the D1 receptor inhibitor SCH23390, the D3 


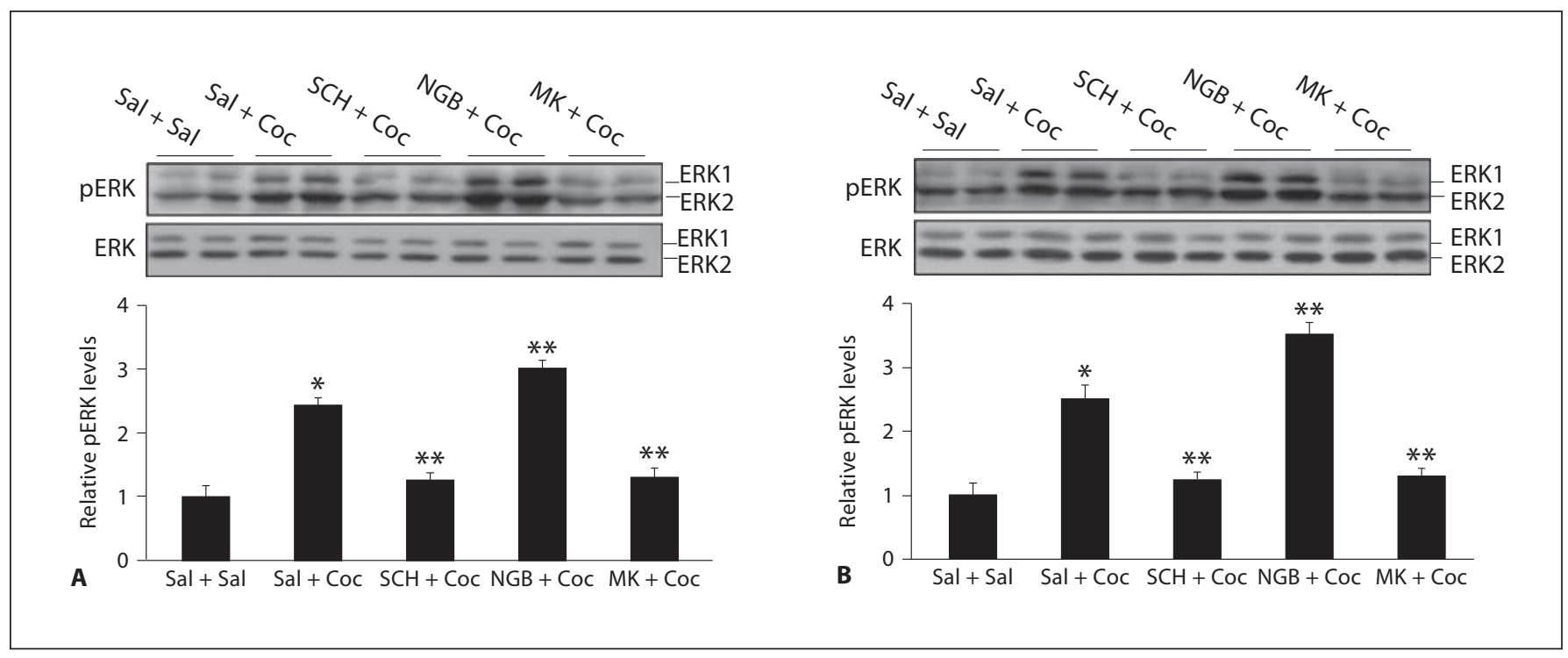

Fig. 6. The activation of ERK after repeated cocaine treatment is oppositely regulated by D1 and D3 receptors and is also NMDA receptor-dependent. Mice $(n=4-6)$ were treated with cocaine $(20$ $\mathrm{mg} / \mathrm{kg}$ ) or saline once a day for 7 days. The D1 receptor inhibitor SCH23390 (0.5 mg/kg), the D3 receptor antagonist NGB2904 (1 $\mathrm{mg} / \mathrm{kg})$, the NMDA receptor inhibitor MK801 $(0.1 \mathrm{mg} / \mathrm{kg})$ and saline were administered $30 \mathrm{~min}$ before cocaine or saline injections. The $\mathrm{NAc}(\mathbf{A})$ and $\mathrm{CPu}(\mathbf{B})$ protein extracts were prepared 20 min after the last injection. Western blot analyses were performed using antibody against dually phosphorylated (Thr202 and Tyr204) ERK (pERK) or total ERK. Data represent the mean \pm SEM. Saline-treated levels were set at 1 for quantifications. ${ }^{*} \mathrm{p}<$ 0.05 compared with saline-treated mice; ${ }^{*} \mathrm{p}<0.05$ compared with cocaine-treated mice (for NAc, $\mathrm{F}_{(4,21)}=282.525$, for $\mathrm{CPu}$, $\left.\mathrm{F}_{(4,21)}=225.475\right)$. receptor inhibitor NGB2904, or the NMDA receptor inhibitor MK801 30 min prior to cocaine or saline administration. Protein extracts were prepared from the $\mathrm{CPu}$ and NAc 20 min following the last cocaine injection, and Western blot analysis was performed to detect the active phosphorylated form of ERK1/2. As shown in figure 6, repeated exposure to cocaine induced a marked increase in ERK phosphorylation. ERK activation was significantly attenuated in the SCH23390, while enhanced in the NGB2904 pretreated mice, indicating that the activation of ERK after chronic cocaine treatment is differentially regulated by $\mathrm{D} 1$ and $\mathrm{D} 3$ receptor activity. In addition, we investigated whether chronic cocaine-induced ERK activation depends upon NMDA receptor activity. We found that MK801 pretreatment significantly attenuated cocaine-induced ERK activation in the NAc and $\mathrm{CPu}$ (fig. 6). Together with the inhibition of cocaine-induced NR1 Ser897 phosphorylation by MK801 (fig. 3), these data indicate that chronic cocaine exposure activates ERK, possibly via the phosphorylation of NR1. Thus, these results suggest that the $\mathrm{D} 1$ and $\mathrm{D} 3$ receptors differentially regulate ERK activation via phosphorylation of NR1 following chronic cocaine treatment.

D1 and D3 Receptor Signaling Mediates Cocaine-Induced Dendritic Changes
To determine whether ERK activation contributes to cocaine-induced structural remodeling in the striatum, we injected mice with the ERK inhibitor SL327 daily for 4 weeks $30 \mathrm{~min}$ prior to cocaine or saline injection. We then performed morphological analyses and found that the pretreatment of mice with SL327 inhibited the cocaine-induced increases in dendrite number $(17.5 \%$ fewer in NAc: $19.33 \pm 0.621$ vs. $23.44 \pm 0.643, \mathrm{p}<0.001, \mathrm{n}=48$ neurons; $18.7 \%$ fewer in CPu: $25.1 \pm 0.85$ vs. $30.88 \pm 0.908, \mathrm{p}<$ $0.001, \mathrm{n}=48$ neurons; fig. $7 \mathrm{~A}, \mathrm{C})$ and spine density $(12.2 \%$ fewer in NAc: $10.8 \pm 0.33$ vs. $12.3 \pm 0.38, \mathrm{p}<0.001, \mathrm{n}=$ 45 dendrites; $14.5 \%$ fewer in $\mathrm{CPu}: 10.62 \pm 0.354$ vs. 12.4 $\pm 0.42, p<0.001, \mathrm{n}=45$ dendrites; fig. $7 \mathrm{~B}, \mathrm{D})$. Sholl analyses indicated that the dendrite-branching pattern was simplified in SL327 pretreated mice compared with control cocaine-treated mice in the NAc and $\mathrm{CPu}$ (fig. 7E; online suppl. table S1-3). The number of dendrites and the density of dendritic spines on medium spiny neurons in the $\mathrm{NAc}$ and $\mathrm{CPu}$ were similar between the SL327 alone-treated and saline-treated mice (online suppl. fig. S1). These data suggest that ERK activation, differentially regulated by D1 and D3 receptor activity, is required for cocaineinduced structural remodeling in the $\mathrm{NAc}$ and $\mathrm{CPu}$. 


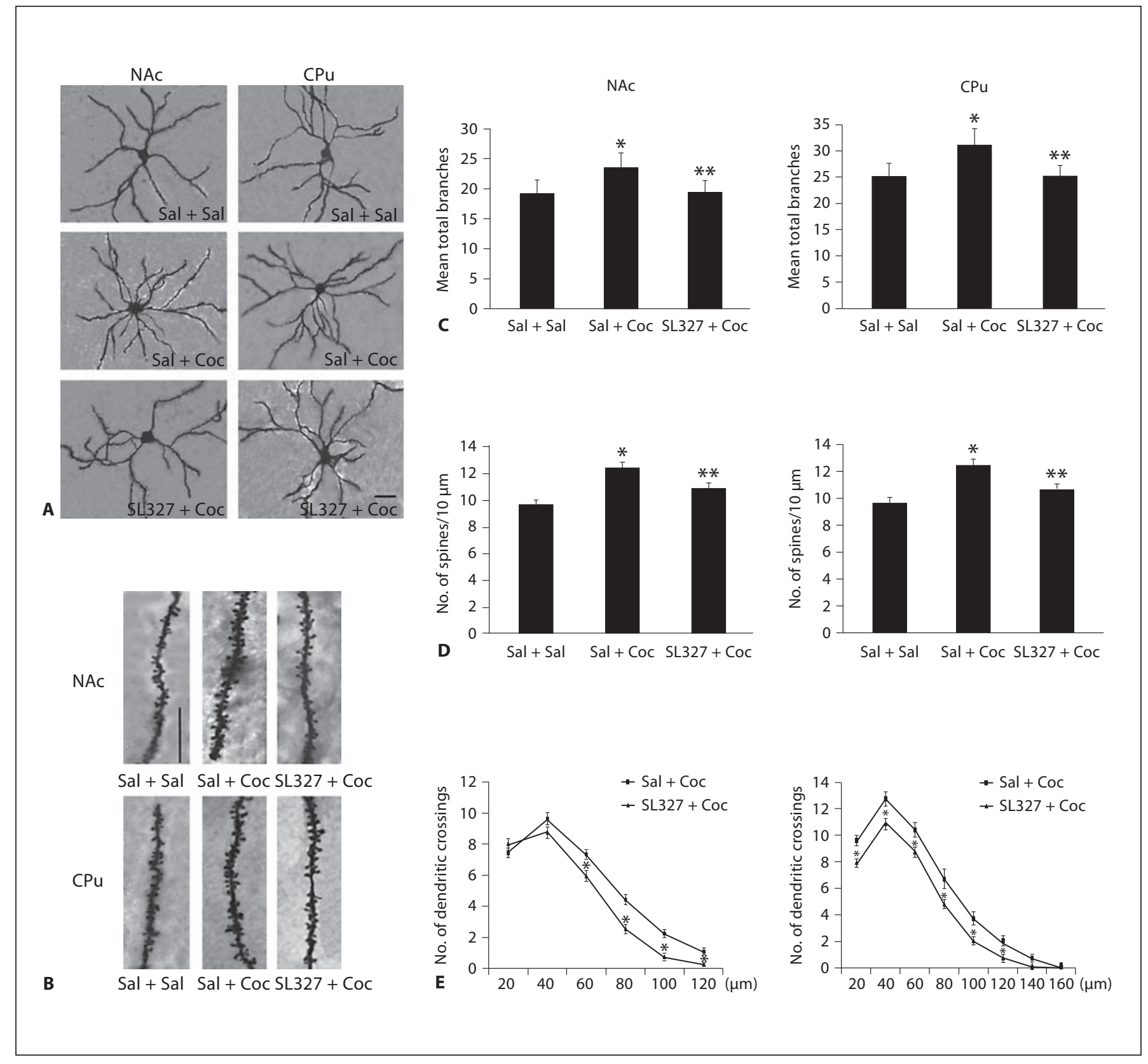

Fig. 7. Inhibition of ERK activity prevents the structural remodeling of dendrites and spines of MSNs in the NAc and CPu after repeated cocaine treatment. Mice $(n=4-6)$ were treated with cocaine $(20 \mathrm{mg} / \mathrm{kg})$ or saline once a day for 4 weeks and then the dendritic morphological analyses were performed. The MEK antagonist SL327 (30 mg/kg dose) and saline were administered 15 min before cocaine or saline injections. A Representative dendritic branching images of MSNs for the NAc and $\mathrm{CPu}$. Scale bar $10 \mu \mathrm{m}$. B Representative dendritic spine images of MSNs for the NAc and CPu. Scale bar $10 \mu \mathrm{m}$. C, D Quantifica- tion of dendritic branching (C) and dendritic spine density (D) in the indicated groups of mice. Data represent mean \pm SEM. ${ }^{*} \mathrm{p}<0.05$ compared with saline-treated mice; ${ }^{* *} \mathrm{p}<0.05$ compared with cocaine-treated mice (for dendritic branching, $\mathrm{F}_{(2,141)}=14.761$ for NAc and $\mathrm{F}_{(2,141)}=12.848$ for $\mathrm{CPu}$; for spine density, $\mathrm{F}_{(2,132)}=16.313$ for $\mathrm{NAc}$ and $\mathrm{F}_{(2,132)}=15.380$ for $\mathrm{CPu}$ ). E The changes in dendrite complexity in the NAc and CPu revealed by Sholl analysis of the intersection number per $20 \mu \mathrm{m}$ radial unit distance from soma of MSNs. ${ }^{*} \mathrm{p}<0.05$ compared with cocaine-treated mice. 

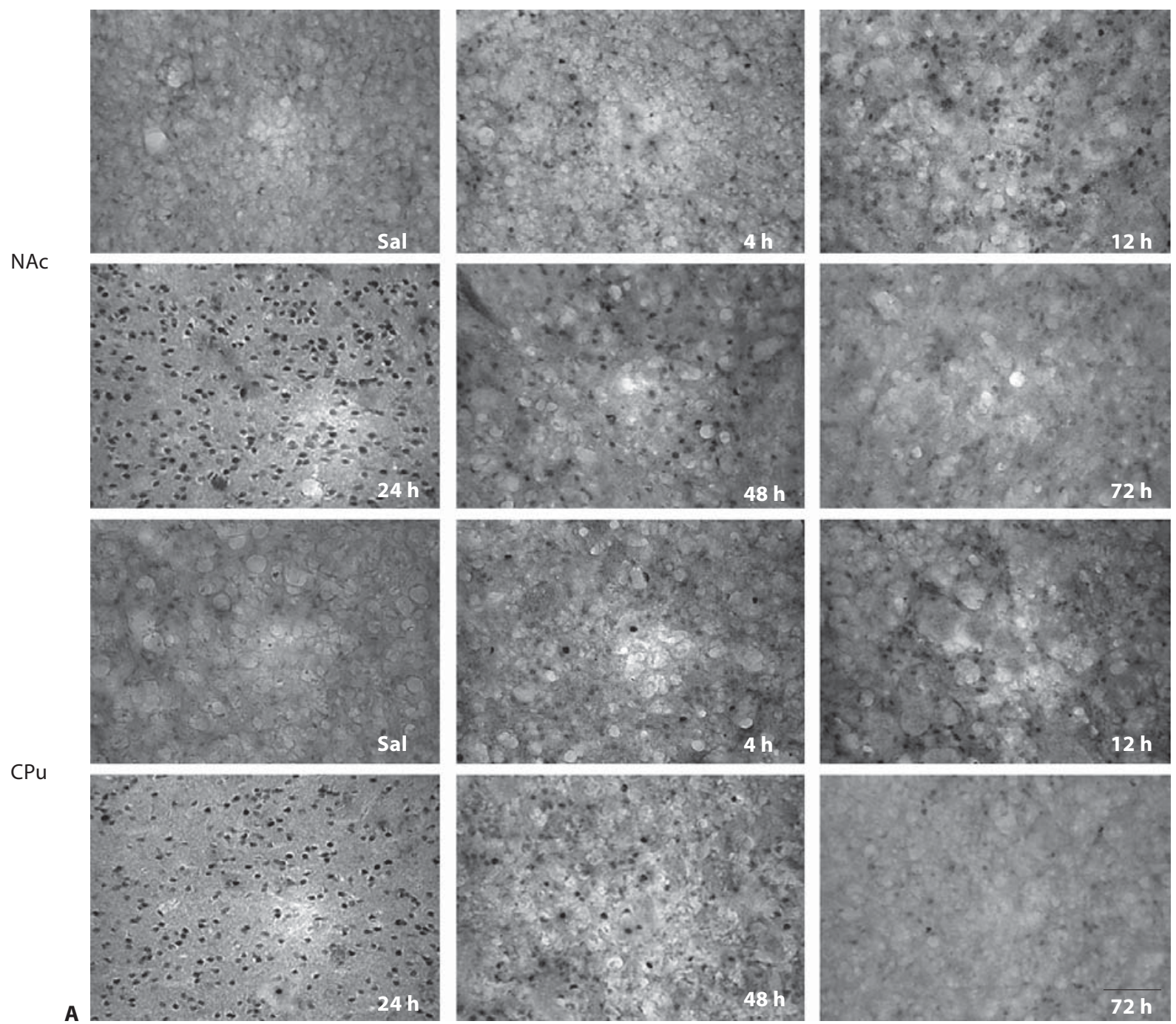

A
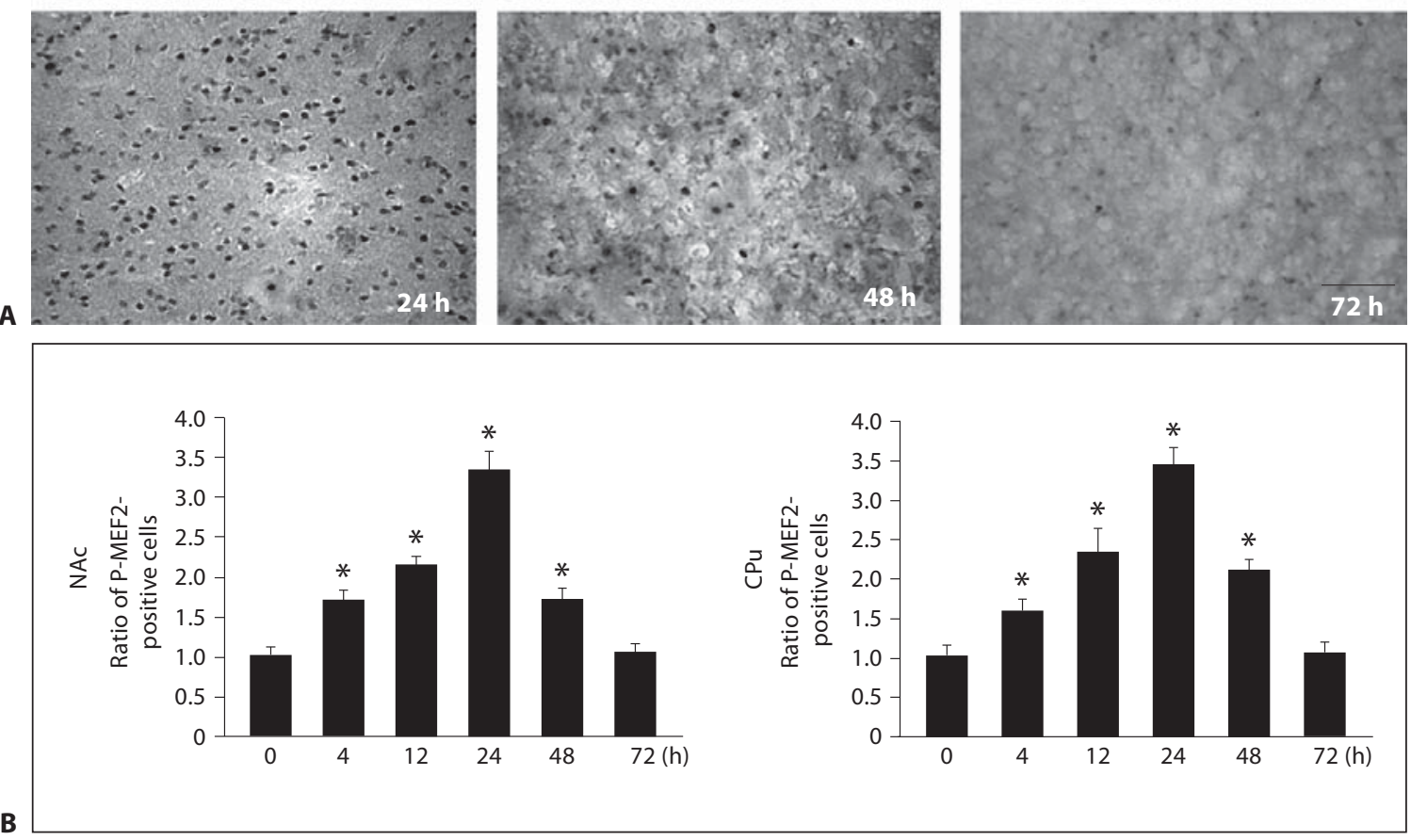

Fig. 8. Time course (A) and quantification (B) of cocaine-induced MEF2 phosphorylation at Ser408 in the NAc and CPu after repeated cocaine exposure. Mice $(\mathrm{n}=4-6)$ were treated with cocaine $(20 \mathrm{mg} / \mathrm{kg})$ or saline once daily for 7 consecutive days. Coronal sections were stained with a phosphorylation site-specific antibody to P-Ser408 MEF2A. P-MEF2-immunoreactive cells in the NAc and $\mathrm{CPu}$ were counted $4,12,24,48$, and $72 \mathrm{~h}$ after the last injection. Scale bar $200 \mu \mathrm{m}$. Data represent ratio of the number of P-Ser408 MEF2A-positive cells in $1 \mathrm{~mm}^{2}$ (mean \pm SEM) area in cocaine-treated mice vs. saline-treated mice. Saline-treated levels were set at 1 for quantifications. ${ }^{*} \mathrm{p}<0.05$ compared with saline-treated mice. 
NAC
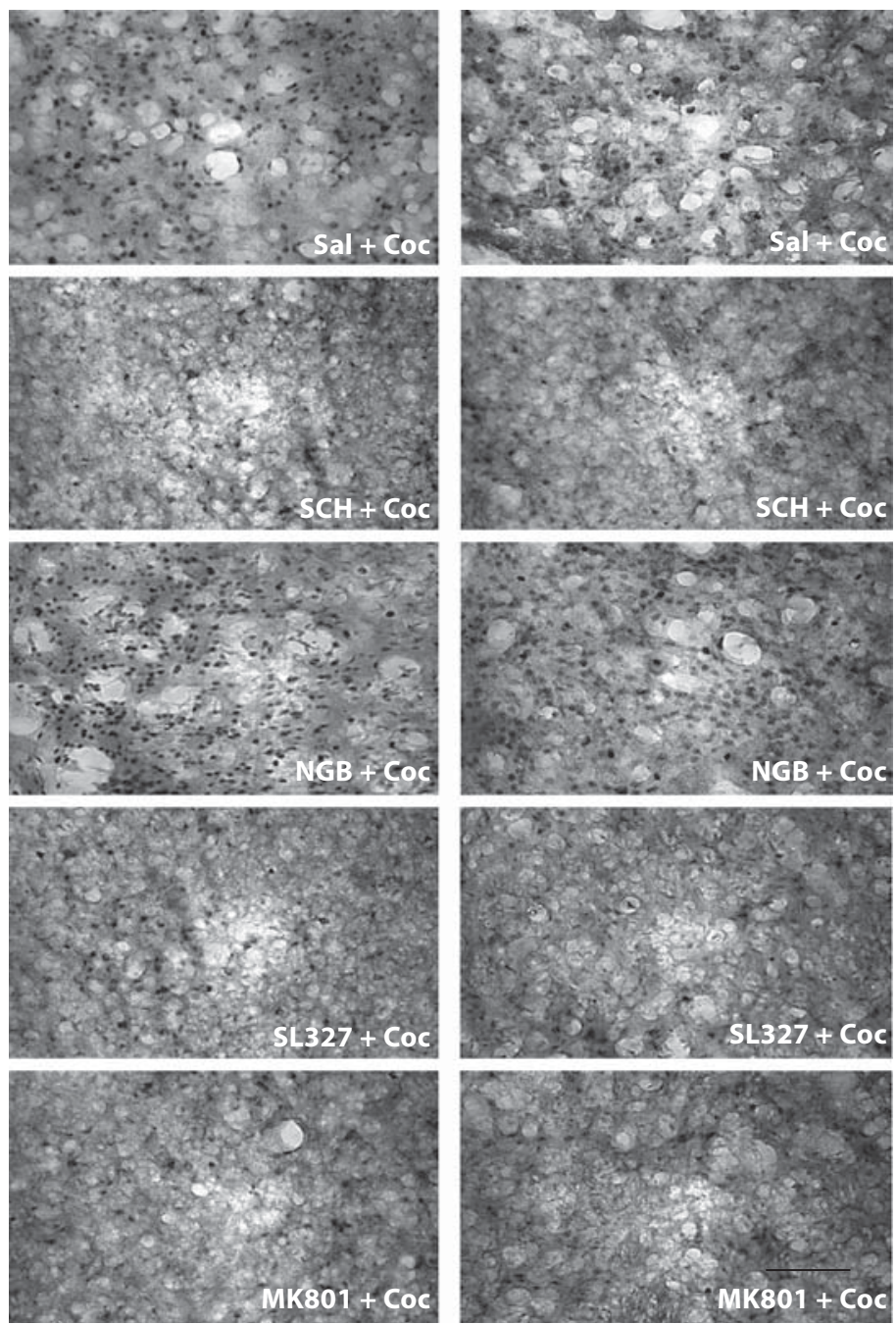

Fig. 9. Cocaine-induced MEF2 phosphorylation at Ser408 is oppositely regulated by dopamine D1 and D3 receptor signaling. Mice $(n=4-6)$ were treated with cocaine in the presence or absence of SCH23390 (0.5 mg/kg), NGB2904 (1 mg/kg), SL327 (30 $\mathrm{mg} / \mathrm{kg})$ or MK801 (0.1 mg/kg) once a day for 7 days. P-MEF2-

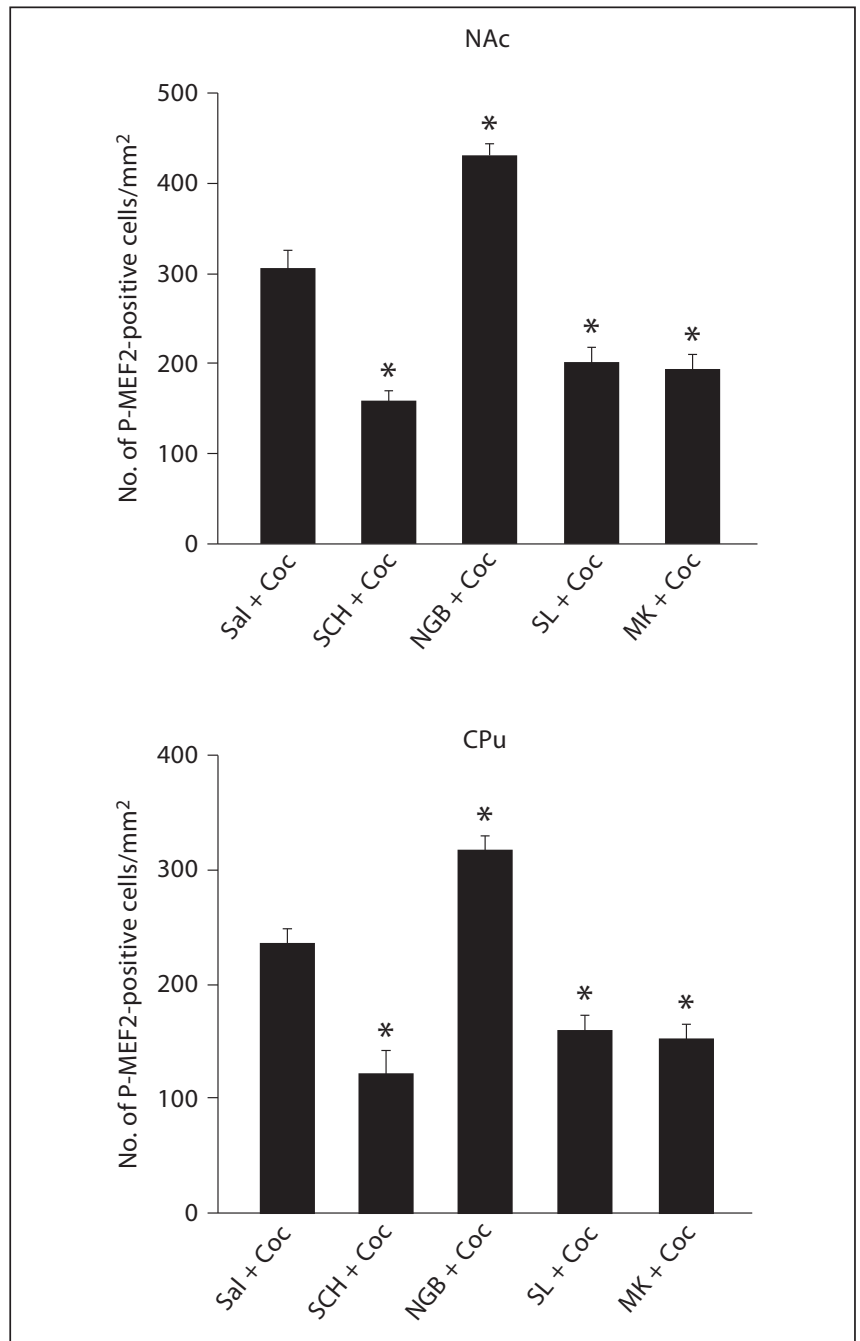

positive cells in the NAc and $\mathrm{CPu}$ were counted $24 \mathrm{~h}$ after the last injection. Scale bar $200 \mu \mathrm{m}$. Data represent total nuclei in $1 \mathrm{~mm}^{2}$ (mean \pm SEM) expressing high P-Ser408 MEF2A immunoreactivity. ${ }^{*} \mathrm{p}<0.05$ compared with cocaine-treated mice.
D1 and D3 Receptor Activity Differentially Modulates MEF2 Activity following Chronic Cocaine Treatment

Members of the MEF2 family (MEF2A-MEF2D) are highly expressed in the brain [58]. A recent study showed that cocaine exposure suppresses the activity of MEF2 in the NAc via the phosphorylation of MEF2 at Ser408/444, and that the reduced activity of MEF2 contributes to the structural remodeling of dendritic spines in the NAc and sensitized responses to cocaine [28]. Importantly, MEF2 activity is regulated by $\mathrm{D} 1$ receptor signaling following cocaine treatment [28]. To determine whether the in- volvement of MEF2 on structural remodeling in the striatum is regulated by $\mathrm{D} 1$ and $\mathrm{D} 3$ receptor signaling pathways, we treated mice with the D1 and D3 receptor antagonists prior to chronic cocaine administration. Animals were then analyzed $4,12,24,48$, and $72 \mathrm{~h}$ following the final injection, and the striatum was isolated for Western blot analysis using an antibody that recognized phospho-Ser408 MEF2A. To measure the cocaineinduced increase in phospho-Ser408 immunoreactivity in the $\mathrm{NAc}$ and $\mathrm{CPu}$, we compared sections from cocaineand saline-treated mice that were processed in parallel. 

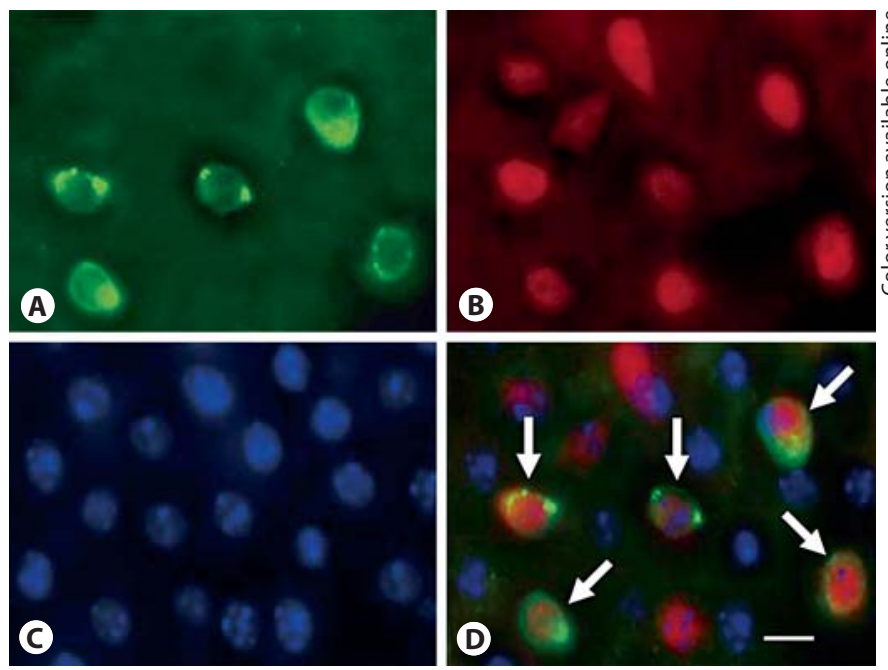

Fig. 10. MEF2 phosphorylation at Ser408 is induced by cocaine administration mostly in dynorphin-expressing neurons in the NAc. Staining for dynorphin (A), P-Ser408 MEF2A (B) and nuclear DNA (C, Hoechst33258) show that phospho-MEF2 is expressed in dynorphin-expressing neurons (D). Double-labeled cells are indicated by white arrows. The results are representative of multiple sections from 4 mice. Sections were obtained $24 \mathrm{~h}$ after the last injection following 7 consecutive days of cocaine treatments. Scale bar $10 \mu \mathrm{m}$.

Immunopositive nuclei were defined by an arbitrary threshold of $5 \times$ background in digitized images using Image Pro Plus [40]. Similar to previous reports [28], cocaine exposure produced a time-dependent increase in MEF2 phosphorylation at Ser408, with a maximal effect observed $24 \mathrm{~h}$ following the last cocaine injection, compared with saline-treated control mice (fig. 8). However, unlike previous reports, the levels of MEF2 phosphorylation returned to baseline $72 \mathrm{~h}$, instead of $48 \mathrm{~h}$, following the final cocaine injection. Importantly, the degree of MEF2 phosphorylation at Ser408 was enhanced in NGB2904-pretreated mice $(\mathrm{p}<0.05)$ and decreased in SCH23390-pretreated mice $(\mathrm{p}<0.05) 24 \mathrm{~h}$ following the final cocaine injection (fig. 9). To determine whether the phosphorylation of MEF2 at Ser408 depends upon NMDA receptor signaling and ERK activation, we pretreated mice with MK801 and SL327. We found that both MK801 and SL327 inhibited the phosphorylation of MEF2 at Ser408 $24 \mathrm{~h}$ following the final cocaine injection (fig. 9). Immunohistochemical analyses revealed that the levels of Ser408 phosphorylation in medium spiny neurons in the NAc and $\mathrm{CPu}$ were similar in mice treated solely with SCH23390, NGB2904, MK801 or SL327, com- pared to saline-treated mice (online suppl. fig. S4). Together, these findings suggest that the D1 and D3 receptors differentially regulate MEF2 phosphorylation following chronic cocaine treatment, likely through NMDA receptor activation and ERK signaling.

To determine further whether cocaine-induced MEF2 phosphorylation occurs primarily in D1 receptor-expressing neurons in the striatum, we analyzed the distribution of phospho-MEF2A and dynorphin in the NAc by double-label immunohistochemistry [59]. We evaluated the phosphorylation of MEF2 phosphorylation at the 24hour time point, when cocaine induces the maximal MEF2A Ser408 phosphorylation (fig. 10B) and dynorphin expression (fig. 10A). As shown in figure 10D, phospho-Ser408 colocalizes with dynorphin in the cytoplasm of cells in the NAc. A subset of phospho-Ser408 immunoreactive neurons did not contain dynorphin immunoreactivity. These results indicate that the phosphorylation of MEF2A at Ser408 occurs primarily in D1 receptorexpressing neurons in the striatum. Together with the regulatory role of MEF 2 in chronic cocaine-induced dendritic remodeling, our data suggest that cocaine exposure activates MEF2, which in turn effects rapid dendritic remodeling in the striatum via dopamine receptor-dependent pathways.

\section{Discussion}

Dendritic remodeling has been hypothesized to contribute to the long-lasting behavioral sensitization seen following chronic cocaine administration $[39,60]$. Likewise, it has recently become clear that the structural plasticity of dendritic spines is associated with synaptic plasticity $[61,62]$. We previously demonstrated that the D1 and D3 receptor signaling elicits opposing regulatory effects upon cocaine-induced gene expression $[18,19]$. In the current study, we found that D1 and D3 receptor activity differentially regulates the cocaine-induced structural remodeling of dendrites and dendritic spines, likely via a mechanism that involves the consecutive activating phosphorylation of NR1, ERK, and MEF2 in the NAc and $\mathrm{CPu}$.

It has been shown that D1 and D3 receptors mediate both opposing and synergistic responses in the NAc and $\mathrm{CPu}[17-19,63,64]$. Our previous studies showed that the D1 and D3 receptors exert opposite regulation on target gene expression by regulating ERK activation and c-Fos induction following cocaine treatment $[18,19]$. A recent study indicated that D1 receptor signaling plays an impor- 
tant role in the long-lasting dendritic changes induced by cocaine exposure [27]. An additional study revealed that D1 receptor signaling contributes to cocaine-induced increases in dendritic spine density via the inhibition of MEF2 activity [28]. In the current study, we found that pretreatment of mice with a D1 receptor inhibitor impaired the ability of cocaine to increase the number of dendrites and the dendritic spine density of medium spiny neurons in the NAc and $\mathrm{CPu}$ following repeated cocaine administration, whereas pretreatment of mice with a D3 receptor inhibitor increased the number of dendrites and spine density in these neurons. These findings indicate that D1 and D3 receptor activities have opposing effects upon chronic cocaine-induced structural remodeling of dendrites and spines in the NAc and $\mathrm{CPu}$.

In the striatum, synapses onto dendritic spines are primarily asymmetric synapses formed by excitatory afferents from the cortex and thalamus [65]. Recent data demonstrated that prenatal exposure to cocaine is associated with increased numbers of asymmetric spine synapses [50]. In most cases, the changes in dendritic structure assessed by Golgi staining are accompanied by changes in the number of synapses analyzed with EM [66-68]. We proposed that the structural changes in medium spiny neurons following cocaine exposure might be associated with an altered number of asymmetric spine synapses in the striatum. Indeed, this turned out to be the case. Importantly, cocaine-induced alternations in the number of asymmetric synapses was inhibited by $\mathrm{D} 1$ receptor inhibition, and increased by D3 receptor inhibition, further emphasizing the opposing roles of D1 and D3 receptors in cocaine-induced remodeling.

NMDA receptors have been implicated in cocaine-induced sensitization $[57,69]$, locomotor hyperactivity [70, 71], gene expression [24, 72], and structural remodeling of dendritic spines [52, 53]. Importantly, dopamine receptor and NMDA receptor activities functionally converge through both direct physical association and the activation of cell signaling pathways [24, 73-77]. One of the molecular connections between dopamine receptor and NMDA receptor activity in striatal neurons is the phosphorylation of NR1 at Ser897 [78], a modification that was recently shown to be increased by NMDA and which is oppositely regulated by $\mathrm{D} 1$ and $\mathrm{D} 3$ receptor activity [19]. In the current study, we found that chronic cocaine treatment induces significant phosphorylation of $\mathrm{NR} 1$ at Ser897 in the NAc and $\mathrm{CPu}$, and this phosphorylation was differentially regulated by $\mathrm{D} 1$ and $\mathrm{D} 3$ receptor activity following chronic cocaine treatment. The phosphorylation of NR1 at Ser897 represents an event that could initiate a variety of molecular programs underlying long-term neuroadaptation to cocaine. In agreement with this concept, we found that the NMDA receptor inhibitor prevented the structural remodeling of dendrites and spines following repeated cocaine treatment. Additionally, we carried out an in vitro PFC analysis. Pyramidal neurons from PFC and medium spiny neurons share a common synaptic architecture involving dopamine and an excitatory input converging onto a spine [79]. The intact PFC contains many intrinsic glutamate neurons, accordingly primary PFC cultures contain dendritic spines $[80,81]$. On the other hand, growth alone in culture, medium spiny neurons from striatum did not express a spontaneous network and were virtually devoid of dendritic spines [82]. Our in vitro analyses showed that MK801 blocked dendritic changes in cultured neurons induced by the D1 receptor agonist, suggesting that D1 receptor signaling may act via NMDA receptor activation. These data suggest that the activity of D1 and D3 receptors mediate phosphorylation of NR1 at Ser897 and further suggest that the D1, D3, and NMDA receptors work cooperatively to facilitate the structural remodeling observed following chronic cocaine treatment.

ERK has been implicated in the rewarding effects of various drugs of abuse. Acute and chronic cocaine administration can activate ERK in different brain regions [20, 21]. ERK activation participates in long-lasting behavioral effects resulting from drug exposure, and is involved in the structural remodeling of dendritic spine synapses [8385]. Importantly, ERK activation following cocaine treatment is differentially regulated by D1 and D3 receptors [18]. In the current study, we found that, in parallel with NR1 phosphorylation at Ser897, ERK activation was increased by $\mathrm{D} 1$ and decreased by $\mathrm{D} 3$ receptor activities, and was also mediated by NMDA receptor activity, indicating that the effects of dopamine receptor activation upon the regulation on ERK activation may occur via phosphorylation of NR1 following chronic cocaine treatment. In addition, we found that ERK activation is required for the structural remodeling of dendrites and dendritic spines following repeated cocaine administration in the NAc and $\mathrm{CPu}$. We previously demonstrated that $\mathrm{D} 1$ and $\mathrm{D} 3$ receptor-mediated ERK activation contributes to target gene expression following repeated cocaine treatment [18]. In extension of these previous findings, our current data indicate that D1 and D3 receptor signaling-mediated ERK activation is required for the cocaine-induced structural remodeling of dendrites and spines.

Members of the MEF2 family are tightly regulated by several distinct signaling pathways, one of which involves 
cyclin-dependent kinase $5(\mathrm{Cdk} 5)$. Cdk5 is a serine/threonine kinase that plays critical roles in neuronal migration, differentiation, and synaptogenesis [86-90]. Chronic cocaine exposure increases the levels and activity of Cdk5 in the NAc [91], and inhibition of Cdk5 activity in the NAc blocks cocaine-induced increases in dendritic spine density [41]. Recent work has shown that MEF2 can regulate excitatory synapse morphogenesis [92, 93], and that cocaine exposure regulates MEF2 function in the NAc to mediate increased in synaptic connectivity [28]. Specifically, chronic cocaine exposure increases MEF2 phosphorylation at its inhibitory Cdk5 site, Ser408/444, in the striatum to suppress its transcriptional activity [28]. Importantly, MEF2 activity in striatal neurons is regulated by dopamine D1 receptor signaling [28]. In the current work, in agreement with previous results [28], we found that chronic cocaine exposure produced a timedependent increase in MEF2 phosphorylation at Ser408, with a maximal effect observed $24 \mathrm{~h}$ following the final cocaine injection. However, unlike previous studies, we observed that the levels of phosphorylated Ser 408 levels returned to baseline at $72 \mathrm{~h}$, rather than $48 \mathrm{~h}$, following cocaine exposure. This difference may result from the difference in species, mouse versus rat, used in these studies [28]. Interestingly, we found that Ser408 phosphorylation at the 24-hour time point is differentially regulated by the activity of $\mathrm{D} 1$ and $\mathrm{D} 3$ receptors. In addition, the NMDA receptor inhibitor and MEK inhibitor also inhibit MEF2 activation induced by chronic cocaine administration. Together, these findings suggest that the activity of MEF2 may be oppositely regulated by the D1 and D3 receptors via NR1 phosphorylation and ERK activation following repeated cocaine treatment.

In the current work, we found that cocaine-induced MEF2 phosphorylation at Ser408 is mostly colocalized with dopamine D1 receptor expression in neurons of the striatum. We previously demonstrated that cocaine-induced ERK activation mostly occurred in D1 receptorexpressing neurons, and that $\mathrm{D} 1$ and $\mathrm{D} 3$ receptors elicit differential regulation on cocaine target gene expression by regulating ERK activation and c-Fos induction [18]. Two of the target genes that are upregulated by c-Fos following 28 days of cocaine treatment are p35, a specific activator of Cdk5, and Cdk5 itself [33]. Although MEF2 is not known to be a direct substrate of ERK, ERK activation may induce p35 and Cdk5 expression via c-Fos and Egrl, and alterations in Cdk5 expression may lead to changes in MEF2 activity [94]. Together, our findings suggest that, during chronic exposure to cocaine, MEF2 activity in D1 receptor-expressing neurons mediates sig- naling events that lead to structural remodeling of dendrites and dendritic spines.

After our manuscript had been submitted for publication, a similar finding was published [95]. However, there are several notable differences between this study and ours. First, Ren et al. [95] provided evidence that D1 receptors, NMDA receptors, and ERK contribute to dendritic remodeling induced by repeated cocaine treatment. However, the interactions between these molecules following cocaine treatment were not detected. Our study focused on the differential regulation of D1 and D3 receptor signaling on cocaine-induced structural remodeling of dendrites and spines, and found that D1 and D3 receptors likely elicit their regulation by consecutively regulating NR1 phosphorylation, ERK activation, and MEF2 activity in the NAc and CPu. Secondly, we provide the first evidence that MEF2, a key regulator of dendritic remodeling after cocaine treatment, is differentially regulated by the $\mathrm{D} 1$ and $\mathrm{D} 3$ receptors through a mechanism likely involving NR1 phosphorylation and ERK activation. Thirdly, the current study provides direct evidence from EM studies showing that chronic cocaine exposure induces alterations in the number of asymmetric spine synapses in the NAc and $\mathrm{CPu}$ mediated via the activities of the dopamine $\mathrm{D} 1$ and $\mathrm{D} 3$ receptors.

In summary, these findings support a model in which the D1 and D3 receptors oppositely regulate cocaine-induced structural remodeling of dendrites and spines, likely via the consecutive regulation of phosphorylation of NR1, ERK activation, and MEF2 activity in the NAc and $\mathrm{CPu}$. In addition, chronic exposure to cocaine results in the altered number of asymmetric spine synapses in the striatum, an effect mediated via D1 and D3 receptor activity. These data provide fundamental insights into the signaling pathways controlling the cocaine-induced structural plasticity that has been implicated in the persistence of drug addiction.

\section{Acknowledgements}

This work is supported by the Natural Science Foundation of China (30770821, 30973129, 81071120), the Program for New Century Excellent Talents in University (NCET-08-0647 and NCET-09-0088), the Key Program of the Natural Science Foundation of Guangdong Province (92510515000008), the Foundation for Science and Technology Research Project of Guangdong (2009A030200015), the Specialized Research Fund for the Doctoral Program of Higher Education (20094433120012), the Key Project of the Chinese Ministry of Education (21132) and the Program for Changjiang Scholars and Innovative Research Team in University (IRT0731). 


\section{References}

1 Koob GF, Sanna PP, Bloom FE: Neuroscience of addiction. Neuron 1998;21:467-476.

$\checkmark 2$ White FJ, Kalivas PW: Neuroadaptations involved in amphetamine and cocaine addiction. Drug Alcohol Depend 1998;51:141-153.

-3 Nestler EJ: Molecular basis of long-term plasticity underlying addiction. Nat Rev Neurosci 2001;2:119-128.

$\checkmark 4$ Hyman SE, Malenka RC: Addiction and the brain: the neurobiology of compulsion and its persistence. Nat Rev Neurosci 2001;2: 695-703.

$\checkmark 5$ Laakso A, Mohn AR, Gainetdinov RR, Caron MG: Experimental genetic approaches to addiction. Neuron 2002;36:213-228.

-6 Robinson TE, Gorny G, Mitton E, Kolb B: Cocaine self-administration alters the morphology of dendrites and dendritic spines in the nucleus accumbens and neocortex. Synapse 2001;39:257-266.

$\checkmark 7$ Norrholm SD, Bibb JA, Nestler EJ, Ouimet CC, Taylor JR, Greengard P: Cocaine-induced proliferation of dendritic spines in nucleus accumbens is dependent on the activity of cyclin-dependent kinase-5. Neuroscience 2003;116:19-22.

$\checkmark 8$ Lee KW, Kim Y, Kim AM, Helmin K, Nairn AC, Greengard P: Cocaine-induced dendritic spine formation in D1 and D2 dopamine receptor-containing medium spiny neurons in nucleus accumbens. Proc Natl Acad Sci USA 2006; 103:3399-3404.

$\checkmark 9$ Russo SJ, Wilkinson MB, Mazei-Robison MS, Dietz DM, Maze I, Krishnan V: Nuclear factor kappa B signaling regulates neuronal morphology and cocaine reward. J Neurosci 2009;29:3529-3537.

-10 LaPlant Q, Vialou V, Covington HE 3rd, Dumitriu D, Feng J, Warren BL, Maze I, Dietz DM, Watts EL, Iñiguez SD, Koo JW, Mouzon E, Renthal W, Hollis F, Wang H, Noonan MA, Ren Y, Eisch AJ, Bolaños CA, Kabbaj M, Xiao G, Neve RL, Hurd YL, Oosting RS, Fan G, Morrison JH, Nestler EJ: Dnmt3a regulates emotional behavior and spine plasticity in the nucleus accumbens. Nat Neurosci 2010;13:1137-1143.

- 11 Maze I, Covington HE 3rd, Dietz DM, LaPlant Q, Renthal W, Russo SJ, Mechanic M, Mouzon E, Neve RL, Haggarty SJ, Ren Y, Sampath SC, Hurd YL, Greengard P, Tarakhovsky A, Schaefer A, Nestler EJ: Essential role of the histone methyltransferase G9a in cocaine-induced plasticity. Science 2010;327: 213-216.

-12 Robinson TE, Kolb B: Alterations in the morphology of dendrites and dendritic spines in the nucleus accumbens and prefrontal cortex following repeated treatment with amphetamine or cocaine. Eur J Neurosci 1999;11:1598-1604.

-13 Civelli O, Bunzow JR, Grandy DK: Molecular diversity of the dopamine receptors. Annu Rev Pharmacol Toxicol 1993;33:281307.
4 Sibley DR, Monsma FJJ, Shen Y: Molecular neurobiology of dopaminergic receptors. Int Rev Neurobiol 1993;35:391-415.

15 Missale C, Nash SR, Robinson SW, Jaber M, Caron MG: Dopamine receptors: from structure to function. Physiol Rev 1998;78: 189-225.

16 Liu XY, Mao LM, Zhang GC, Papasian CJ, Fibuch EE, Lan HX Zhou HF, Xu M, Wang JQ: Activity-dependent modulation of limbic dopamine D3 receptors by CaMKII. Neuron 2009;61:425-438.

17 Xu M, Koeltzow TE, Santiago GT, Moratalla R, Cooper DC, Hu XT, White NM, Graybiel AM, White FJ, Tonegawa S: Dopamine D3 receptor mutant mice exhibit increased behavioral sensitivity to concurrent stimulation of D1 and D2 receptors. Neuron 1997;19: 837-848.

18 Zhang L, Lou D, Jiao H, Zhang D, Wang X, Xia Y, Zhang J, Xu M: Cocaine-induced intracellular signaling and gene expression are oppositely regulated by the dopamine D1 and D3 receptors. J Neurosci 2004;24:33443354.

19 Jiao HY, Zhang L, Gao F, Lou D, Zhang J, Xu M: Dopamine $\mathrm{D}(1)$ and $\mathrm{D}(3)$ receptors oppositely regulate NMDA- and cocaine-induced MAPK signaling via NMDA receptor phosphorylation. J Neurochem 2007;103:840848.

20 Berhow MT, Hiroi N, Nestler EJ: Regulation of ERK (extracellular signal regulated kinase), part of the neurotrophin signal transduction cascade, in the rat mesolimbic dopamine system by chronic exposure to morphine or cocaine. J Neurosci 1996;16: 4707-4715.

21 Valjent E, Corvol JC, Pages C, Besson MJ, Maldonado R, Caboche J: Involvement of the extracellular signal-regulated kinase cascade for cocaine-rewarding properties. J Neurosci 2000;20:8701-8709.

22 Choe ES, Chung KT, Mao L, Wang JQ: Amphetamine increases phosphorylation of extracellular signal-regulated kinase and transcription factors in the rat striatum via group I metabotropic glutamate receptors. Neuropsychopharmacology 2002;27:565-575.

23 Mazzucchelli C, Vantaggiato C, Ciamei A, Fasano S, Pakhotin P, Krezel W, Welzl H, Wolfer DP, Pagès G, Valverde O, Marowsky A, Porrazzo A, Orban PC, Maldonado R, Ehrengruber MU, Cestari V, Lipp HP, Chapman PF, Pouysségur J, Brambilla R: Knockout of ERK1 MAP kinase enhances synaptic plasticity in the striatum and facilitates striatal-mediated learning and memory. Neuron 2002;34:807-820.

24 Dudman JT, Eaton ME, Rajadhyaksha A, Macías W, Taher M, Barczak A, Kameyama K, Huganir R, Konradi C: Dopamine D1 receptors mediate CREB phosphorylation via phosphorylation of the NMDA receptor at Ser897-NR1. J Neurochem 2003;87:922-934.
25 Valjent E, Pascoli V, Svenningsson P, Paul S, Enslen H, Corvol JC, Stipanovich A, Caboche J, Lombroso PJ, Nairn AC, Greengard P, Hervé D, Girault JA: Regulation of a protein phosphatase cascade allows convergent dopamine and glutamate signals to activate ERK in the striatum. Proc Natl Acad Sci USA 2005; 102:491-496.

26 Liu NY, Zhang L, Zhang L, Wang X: Dopamine D3 receptors mediated jak2 and GABAA $\alpha 1$ gene expression induced by cocaine. Chin Med J (Engl) 2007;120:910-914.

$>27$ Lee KW, Kim Y, Kim AM, Helmin K, Nairn AC, Greengard P: Cocaine-induced dendritic spine formation in D1 and D2 dopamine receptor-containing medium spiny neurons in nucleus accumbens. Proc Natl Acad Sci USA 2006;103:3399-3404.

-28 Pulipparacharuvil S, Renthal W, Hale CF, Taniguchi M, Xiao G, Kumar A, Russo SJ, Sikder D, Dewey CM, Davis MM, Greengard P, Nairn AC, Nestler EJ, Cowan CW: Cocaine regulates MEF2 to control synaptic and behavioral plasticity. Neuron 2008;59:621-633.

29 Shang H, Wei H, Yue B, Xu P, Huang H: Microsatellite analysis in two populations of Kunming mice. Lab Anim 2009;43:34-40.

-30 Zhang D, Zhang L, Tang Y, Zhang Q, Lou D, Sharp FR, Zhang J, Xu M: Repeated cocaine administration induces gene expression changes through the dopamine D1 receptors. Neuropsychopharmacology 2005;30: 1443-1454.

-31 Zhang D, Zhang L, Lou DW, Nakabeppu Y, Zhang J, Xu M: The dopamine D1 receptor is a critical mediator for cocaine-induced gene expression. J Neurochem 2002;82:14531464

32 Xi ZX, Gardner EL: Pharmacological actions of NGB 2904, a selective dopamine D3 receptor antagonist, in animal models of drug addiction. CNS Drug Rev 2007;13:240-259.

-33 Zhang J, Zhang L, Jiao H, Zhang Q, Zhang D, Lou D, Katz JL, Xu M: c-fos facilitates the acquisition and extinction of cocaine-induced persistent changes. J Neurosci 2006;26: 13287-13296.

34 Wolf ME, Jeziorski M: Coadministration of MK-801 with amphetamine, cocaine or morphine prevents rather than transiently masks the development of behavioral sensitization. Brain Res 1993;613:291-294.

-35 Xi ZX, Newman AH, Gilbert JG, Pak AC, Peng XQ, Ashby CR Jr, Gitajn L, Gardner EL: The novel dopamine D3 receptor antagonist NGB 2904 inhibits cocaine's rewarding effects and cocaine-induced reinstatement of drug-seeking behavior in rats. Neuropsychopharmacology 2006;31:1393-1405

36 Pritchard LM, Newman AH, McNamara RK, Logue AD, Taylor B, Welge JA, Xu M, Zhang J, Richtand NM: The dopamine D3 receptor antagonist NGB 2904 increases spontaneous and amphetamine-stimulated locomotion. Pharmacol Biochem Behav 2007;86:718-726. 
-37 Robinson, TE, Kolb B: Persistent structural modifications in nucleus accumbens and prefrontal cortex neurons produced by previous experience with amphetamine. J Neurosci 1997; 17:8491-8497.

38 Flores, C, Wen, X, Labelle-Dumais, C, and Kolb, B: Chronic phencyclidine treatment increases dendritic spine density in prefrontal cortex and nucleus accumbens neurons. Synapse 2007;61:978-984.

-39 Robinson TE and Kolb B: Alterations in the morphology of dendrites and dendritic spines in the nucleus accumbens and prefrontal cortex following repeated treatment with amphetamine or cocaine. Eur J Neurosci 1999;11:1598-1604.

-40 Li J, Guo Y, Schroeder FA, Youngs RM, Schmidt TW, Ferris C Konradi C, Akbarian $\mathrm{S}$ : Dopamine D2-like antagonists induce chromatin remodeling in striatal neurons through cyclic AMP-protein kinase A and NMDA receptor signaling. J Neurochem 2004;90:1117-1131.

-41 Norrholm SD, Bibb JA, Nestler EJ, Ouimet CC, Taylor JR, Greengard P: Cocaine-induced proliferation of dendritic spines in nucleus accumbens is dependent on the activity of cyclin-dependent kinase-5. Neuroscience 2003;116:19-22.

-42 Meng Y, Zhang Y, Tregoubov V, Janus C, Cruz L, Jackson M, Lu WY, MacDonald JF, Wang JY, Falls DL, Jia Z: Abnormal spine morphology and enhanced LTP in LIMK-1 knockout mice. Neuron 2002;35:121-133.

$\checkmark 43$ Antonopoulos J, Dori I, Dinopoulos A, Chiotelli M, Parnavelas JG: Postnatal development of the dopaminergic system of the striatum in the rat. Neuroscience 2002;110:245256.

44 Gao, C, Wolf, ME: Dopamine receptors regulate NMDA receptor surface expression in prefrontal cortex neurons. J Neurochem 2008;106:2489-2501.

45 Sun X, Milovanovic M, Zhao Y, Wolf ME: Acute and chronic dopamine receptor stimulation modulates AMPA receptor trafficking in nucleus accumbens neurons cocultured with prefrontal cortex neurons. J Neurosci 2008;28:4216-4230.

46 McCroskery S, Bailey A, Lin L, Daniels MP: Transmembrane agrin regulates dendritic filopodia and synapse formation in mature hippocampal neuron cultures. Neuroscience 2009;163:168-179.

47 Richtand NM: Behavioral sensitization, alternative splicing, and D3 dopamine receptor-mediated inhibitory function. Neuropsychopharmacology 2006;31:2368-2375.

48 Yuan J., Chen X, Brodbeck R, Primus R, Braun J, Wasley JW, Thurkauf A: NGB 2904 and NGB 2849: two highly selective dopamine D3 receptor antagonists. Bioorg Med Chem Lett 1998;8:2715-2718.
-49 Newman AH, Cao J, Bennett CJ, Robarge MJ, Freeman RA, Luedtke RR: N-(4-[4-(2,3dichlorophenyl)piperazin-1-yl]butyl, butenyl and butynyl)arylcarboxamides as novel dopamine $\mathrm{D}(3)$ receptor antagonists. Bioorg Med Chem Lett 2003;13:2179-2183.

50 Morrow BA, Hajszan T, Leranth C, Elsworth JD, Roth RH: Prenatal exposure to cocaine is associated with increased number of spine synapses in rat prelimbic cortex. Synapse 2007;61:862-865.

51 Nikonenko I, Jourdain P, Alberi S, Toni N, Muller D: Activity-induced changes of spine morphology. Hippocampus 2002;12:585591.

52 Wong RO, Ghosh A: Activity-dependent regulation of dendritic growth and patterning. Nat Rev Neurosci 2002;3:803-812.

53 Tolias KF, Bikoff JB, Burette A, Paradis S, Harrar D, Tavazoie S, Weinberg RJ, Greenberg ME: The Rac1-GEF Tiam1 couples the NMDA receptor to the activity-dependent development of dendritic arbors and spines. Neuron 2005;45:525-538.

54 Espinosa JS, Wheeler DG, Tsien RW, Luo L: Uncoupling dendrite growth and patterning: single-cell knockout analysis of NMDA receptor 2B. Neuron 2009;62:205-217.

55 Karler R, Calder LD, Bedingfield JB: Cocaine behavioral sensitization and the excitatory amino acids. Psychopharmacology 1994; 115:305-310.

56 Kim HS, Park WK, Jang CG, Oh S: Inhibition by MK- 801 of cocaine-induced sensitization, conditioned place preference, and dopamine-receptor supersensitivity in mice. Brain Res Bull 1996;40:201-207.

57 Li Y, Hu X-T, Berney TG, Vartanian AJ, Stine CD, Wolf ME, White FJ: Both glutamate receptor antagonists and prefrontal cortex lesions prevent induction of cocaine sensitization and associated neuroadaptations. Synapse 1999;34:169-180.

58 Lyons GE, Micales BK, Schwarz J, Martin JF, Olson EN: Expression of mef2 genes in the mouse central nervous system suggests a role in neuronal maturation. J Neurosci 1995; 15 : 5727-5738.

59 Moratalla R, Elibol B, Vallejo M, Graybiel AM: Network-level changes in expression of inducible Fos-Jun proteins in the striatum during chronic cocaine treatment and withdrawal. Neuron 1996;17:147-156.

60 Kiraly DD, Ma XM, Mazzone CM, Xin X, Mains RE, Eipper BA: Behavioral and morphological responses to cocaine require kalirin7. Biol Psychiatry 2010;68:249-255.

61 Kopec CD, Li B, Wei W, Boehm J, Malinow R: Glutamate receptor exocytosis and spine enlargement during chemically induced long-term potentiation. J Neurosci 2006;26: 2000-2009.
62 Xie Z, Srivastava DP, Photowala H, Kai L, Cahill ME, Woolfrey KM, Shum CY, Surmeier DJ, Penzes P: Kalirin-7 controls activity-dependent structural and functional plasticity of dendritic spines. Neuron 2007; 56:640-656.

63 Surmeier DJ, Song WJ, Yan Z: Coordinated expression of dopamine receptors in neostriatal medium spiny neurons. J Neurosci 1996; 16:6579-6591.

64 Ridray S, Griffon N, Mignon V, Souil E, Carboni S, Diaz J, Schwartz JC, Sokoloff P: Coexpression of dopamine D1 and D3 receptors in islands of Calleja and shell of nucleus accumbens of the rat: opposite and synergistic functional interactions. Eur J Neurosci 1998; 10:1676-1686.

-65 Ingham CA, Hood SH, Taggart P, Arbuthnott GW: Plasticity of synapses in the rat neostriatum after unilateral lesion of the nigrostriatal dopaminergic pathway. J Neurosci $1998 ; 18: 4732-4743$

66 Greenough WT, Bailey CH: The anatomy of a memory: convergence of results across a diversity of tests. Trends. Neurosci 1988; 11:142-147.

67 Kolb B, Whishaw IQ: Brain plasticity and behavior. Annu Rev Psychol 1998;49:43-64.

68 Robinson TE, Kolb B: Structural plasticity associated with exposure to drugs of abuse. Neuropharmacology 2004;47(suppl 1):3346.

69 Battisti JJ, Shreffler CB, Uretsky NJ, Wallace LJ: NMDA antagonists block expression of sensitization of amphetamine- and apomorphine-induced stereotypy. Pharmacol Biochem Behav 2000;67:241-246.

70 Druhan JP, Wilent WB: Effects of the competitive N-methyl-D-aspartate receptor antagonist, CPP, on the development and expression of conditioned hyperactivity and sensitization induced by cocaine. Behav Brain Res 1999;102:195-210.

71 Uzbay IT, Wallis CJ, Lal H, Forster MJ: Effects of NMDA receptor blockers on cocaine-stimulated locomotor activity in mice. Behav Brain Res 2000;108:57-61.

72 Konradi C, Leveque JC, Hyman SE: Amphetamine and dopamine-induced immediate early gene expression in striatal neurons depends on postsynaptic NMDA receptors and calcium. J Neurosci 1996;16:4231-4239.

73 Lee FJ, Xue S, Pei L, Vukusic B, Chéry N, Wang Y, Wang YT, Niznik HB, Yu XM, Liu F: Dual regulation of NMDA receptor functions by direct protein-protein interactions with the dopamine D1 receptor. Cell 2002; 111:219-230.

74 XY, Chu XP, Mao LM, Wang M, Lan HX, Li $\mathrm{MH}$, Zhang GC, Parelkar NK, Fibuch EE, Haines M, Neve KA, Liu F, Xiong ZG, Wang JQ: Modulation of D2R-NR2B interactions in response to cocaine. Neuron 2006;52:897909. 
75 Cepeda C, Levine MS: Where do you think you are going? The NMDA-D1 receptor trap. Sci STKE 2006;333:pe20.

76 Kruse MS, Prémont J, Krebs MO, Jay TM: Interaction of dopamine D1 with NMDA NR1 receptors in rat prefrontal cortex. Eur Neuropsychopharmacol 2009; 19:296-304.

-77 Lee DK, Bian S, Rahman MA, Shim YB, Shim I, Choe ES: Repeated cocaine administration increases N-methyl-D-aspartate NR1 subunit, extracellular signal-regulated $\mathrm{ki}$ nase and cyclic AMP response elementbinding protein phosphorylation and glutamate release in the rat dorsal striatum. Eur J Pharmacol 2008;590:157-162.

-78 Tingley WG, Ehlers MD, Kameyama K, Doherty C, Ptak JB, Riley CT, Huganir RL: Characterization of protein kinase $\mathrm{A}$ and protein kinase $\mathrm{C}$ phosphorylation of the $\mathrm{N}$ methyl-D-aspartate receptor NR1 subunit using phosphorylation site-specific antibodies. J Biol Chem 1997;272:5157-5166.

-79 Sesack SR, Carr DB, Omelchenko N, Pinto A: Anatomical substrates for glutamate-dopamine interactions: evidence for specificity of connections and extrasynaptic actions. Ann NY Acad Sci 2003;1003:36-52.

-80 Sun X, Zhao Y, Wolf ME: Dopamine receptor stimulation modulates AMPA receptor synaptic insertion in prefrontal cortex neurons. J Neurosci 2005;25:7342-7351.

-81 Wolf ME, Mangiavacchi S, Sun X: Mechanisms by which dopamine receptors may influence synaptic plasticity. Ann NY Acad Sci 2003;1003:241-249.
$>2$ Segal M, Greenberger V, Korkotian E: Formation of dendritic spines in cultured striatal neurons depends on excitatory afferent activity. Eur J Neurosci 2003;17:2573-2585.

83 Alonso M, Medina JH, Pozzo-Miller: LERK $1 / 2$ activation is necessary for BDNF to increase dendritic spine density in hippocampal CA1 pyramidal neurons. Learn Mem 2004;11:172-178.

84 Lu L, Koya E, Zhai H, Hope BT, Shaham Y: Role of ERK in cocaine addiction. Trends Neurosci 2006;29:695-703.

85 Girault JA, Valjent E, Caboche J, Hervé D: ERK2: a logical AND gate critical for druginduced plasticity? Curr Opin Pharmacol 2007;7:77-85.

86 Lee JH, Kim KT: Induction of cyclin-dependent kinase 5 and its activator p35 through the extracellular-signal-regulated kinase and protein kinase A pathways during retinoic-acid mediated neuronal differentiation in human neuroblastoma SK-N-BE (2) C cells. J Neurochem 2004;91:634-647.

87 Fu WY, Chen Y, Sahin M, Zhao XS, Shi L, Bikoff JB Lai KO, Yung WH, Fu AK, Greenberg ME, Ip NY: Cdk5 regulates EphA4-mediated dendritic spine retraction through an ephexin1-dependent mechanism. Nat Neurosci 2007; 10:67-76.

88 Lagace DC, Benavides DR, Kansy JW, Mapelli M, Greengard P, Bibb JA, Eisch AJ: Cdk5 is essential for adult hippocampal neurogenesis. Proc Natl Acad Sci USA 2008; 105: 18567-18571.

$>89$ Zhang J, Cicero SA, Wang L, Romito-Digiacomo RR, Yang Y, Herrup K: Nuclear localization of Cdk5 is a key determinant in the postmitotic state of neurons. Proc Natl Acad Sci USA 2008;105:8772-8777.
90 Lai KO, Ip NY: Recent advances in understanding the roles of Cdk5 in synaptic plasticity. Biochim Biophys Acta 2009;1792:741745.

91 Bibb JA, Chen J, Taylor JR, Svenningsson P, Nishi A, Snyder GL, Yan Z, Sagawa ZK, Ouimet CC, Nairn AC, Nestler EJ, Greengard P: Effects of chronic exposure to cocaine are regulated by the neuronal protein $\mathrm{Cdk} 5$. Nature 2001;410:376-380.

$\checkmark 92$ Flavell SW, Cowan CW, Kim TK, Greer PL, Lin Y, Paradis S, Griffith EC, Hu LS, Chen C, Greenberg ME: Activity-dependent regulation of MEF2 transcription factors suppresses excitatory synapse number. Science 2006; 311:1008-1012.

$\checkmark 93$ Shalizi A, Gaudillière B, Yuan Z, Stegmüller J, Shirogane T, Ge Q, Tan Y, Schulman B, Harper JW, Bonni A: A calcium-regulated MEF2 sumoylation switch controls postsynaptic differentiation. Science 2006;311:10121017.

$\checkmark 94$ Harada T, Morooka T, Ogawa S, Nishida E: ERK induces p35, a neuron-specific activator of Cdk5, through induction of Egrl. Nat Cell Biol 2001;3:453-459.

$>95$ Ren Z, Sun WL, Jiao H, Zhang D, Kong H, Wang X, Xu M: Dopamine D1 and N-methyl-D-aspartate receptors and extracellular signal-regulated kinase mediate neuronal morphological changes induced by repeated cocaine administration. Neuroscience 2010; 168:48-60. 